The research program of the Center for Economic Studies (CES) produces a wide range of theoretical and empirical economic analyses that serve to improve the statistical programs of the U.S. Bureau of the Census. Many of these analyses take the form of CES research papers. The papers are intended to make the results of CES research available to economists and other interested parties in order to encourage discussion and obtain suggestions for revision before publication. The papers are unofficial and have not undergone the review accorded official Census Bureau publications. The opinions and conclusions expressed in the papers are those of the authors and do not necessarily represent those of the U.S. Bureau of the Census. Republication in whole or part must be cleared with the authors.

\title{
THE CONTRIBUTION OF ESTABLISHMENT BIRTHS AND DEATHS TO EMPLOYMENT GROWTH
}

\author{
By \\ James R. Spletzer* \\ Bureau of Labor Statistics \\ 2 Massachusetts Avenue, N.E., Suite 4945 \\ Washington, D.C. 20212 \\ CES 98-5 April 1998
}

All papers are screened to ensure that they do not disclose confidential information. Persons who wish to obtain a copy of the paper, submit comments about the paper, or obtain general information about the series should contact Sang V. Nguyen, Editor, Discussion Papers, Center for Economic Studies, Washington Plaza II, Room 211, Bureau of the Census, Washington, DC 20233-6101, (301-457-1882) or INTERNET address

snguyen@info. census.gov. 


\section{Abstract}

The purpose of this paper is to examine how establishment births and deaths contribute to job creation, job destruction, and net employment growth at different frequencies of measurement. The longitudinal data are constructed from quarterly unemployment insurance microdata, and are essentially a census of establishments in all industries. Defining establishment births and deaths turns out to be an exercise in how to use cross-sectional administrative data for longitudinal research purposes. The analysis of job flows indicates that the importance of establishment births and deaths on a quarterly time frame is relatively small but certainly non-trivial, whereas births and deaths account for roughly half of all jobs created and destroyed on a triennial time frame.

Key Words: Longitudinal establishment microdata, job creation and job destruction, net employment growth.

*The author would like to thank many persons in the Division of Occupational and Administrative Statistics and the Division of Business Establishment Systems at BLS for answering numerous questions about the ES-202 data. The author would also like to thank seminar participants at BLS and the Census Bureau's Center for Economic Studies for helpful comments. All analytic results and any opinions expressed in this paper are those of the author and not necessarily those of the BLS or any BLS staff members. 


\section{Introduction}

The relatively recent development of longitudinal establishment datasets has generated quite a bit of excitement in both the academic and the statistical communities. From this literature, we have learned that there is a large amount of volatility at the individual establishment level that underlies the smooth time series of aggregate employment growth. The descriptive statistics coming out of this literature have not only stimulated the review and updating of existing labor market theories, but have also stimulated the U.S. statistical agencies to develop their administrative datasets in such a way so as to produce longitudinal job flow statistics. The purpose of this paper is to use a new longitudinal database from the Bureau of Labor Statistics (BLS) in order to examine how establishment births and deaths contribute to job creation, job destruction, and net employment growth at different frequencies of measurement.

Despite all that we have learned about the labor market from the existing job flows literature, the conclusions that can be drawn from these studies are somewhat limited. First, almost all of the existing work using U.S. data has been restricted to the manufacturing sector. Recent work by several authors has illustrated how job creation and job destruction in manufacturing may not be representative of the entire U.S. economy. ${ }^{1}$ A second limitation is that most of the existing empirical work on job flows, either by choice or by necessity, is based upon data that excludes the smallest establishments. ${ }^{2}$ Since most establishment births and deaths are quite small, at least in the short run, we are thus unsure how these births and deaths influence employment growth. While data that focuses on large establishments will cover most employment, an analysis of job flows depends on the magnitude of employment flows at continuing establishments relative to the incidence and average size of establishment births and deaths.

The longitudinal database introduced in this paper is not subject to either of these limitations. The microdata upon which this paper is based are the unemployment insurance reports that employers in the U.S. are required to file with the states, and these data are essentially a quarterly

\footnotetext{
1 The studies by Davis and Haltiwanger (1990, 1992), Davis, Haltiwanger, and Schuh (1993, 1996), and Dunne, Roberts and Samuelson (1988, 1989a, 1989b) have all used manufacturing data housed at the Center for Economic Studies at the U.S. Census Bureau. Recent work with unemployment insurance data by Anderson and Meyer (1994), Foote (1997), Lane, Stevens, and Burgess (1996), and Leonard (1987) has looked at other sectors of the economy.

${ }^{2}$ Small plants with less than five employees are not in the sample frame of the Annual Survey of Manufactures (ASM) data used by Davis, Haltiwanger, and Schuh (1996); these plants represent about one-third of all plants and about 4 to 7 percent of employment. Using the Census of Manufactures, Dunne, Roberts and Samuelson (1989a) exclude manufacturing plants with less than 5 employees; these excluded plants account for between 30 and 40 percent of all plants but represent only one percent of
} 
census of establishments in all industries. The quarterly observations on each establishment are ideal when looking at topics such as short run employment growth immediately following birth and immediately preceding death. A detailed description of these data and the construction of the longitudinal dataset is provided in section II of this paper. Because of the focus on births and deaths in this paper, special attention is given to the longitudinal linkage algorithm used to minimize the incidence of spurious births and deaths.

In section III, I define establishment births and deaths. This turns out to be an exercise that illustrates the problems associated with using cross-sectional administrative data for longitudinal research purposes. Since the topic of this paper is how establishment births and deaths contribute to job flows, the appropriate definition of establishment births and deaths is the first and last date of positive employment. I contrast this with the simpler approach of defining births and deaths as the appearance and disappearance of the establishment from the dataset. The substantive difference between these two definitions is that businesses in the unemployment insurance system are allowed to report zero employment for several quarters after they have effectively closed. This turns out to matter for our understanding of the establishment's life cycle, in that defining births and deaths as the first and last dates of positive employment leads to a hazard function for new business death that is monotonically decreasing, whereas defining births and deaths as the appearance and disappearance of the establishment from the dataset leads to a hazard function that exhibits an inverted-U shape. This difference helps us distinguish between the informational assumptions inherent in competing theories of business births, their growth, and their likelihood of survival.

The analysis of how births, deaths, and continuing establishments contribute to employment growth is contained in section IV. If births and deaths are relatively small, as measured by employment, is a study of how births and deaths contribute to job creation and job destruction warranted? The answer to this question, as noted by Hamermesh (1993), depends on the frequency over which employment growth is measured. For example, job creation attributable to births measured at high frequencies (such as quarterly) will be understated if establishment growth is a gradual process, whereas job creation measured at low frequencies (such as triennial) will miss any establishments that were born and died within the period. I find that the importance of establishment births and deaths on a quarterly time frame is relatively small but certainly non-trivial, whereas births and deaths account for roughly half of all jobs created and destroyed on a triennial time frame.

employment. The firm sample used by Anderson and Meyer (1994) includes only firms with at least 50 employees; this sample accounts for 83 percent of employment. 
The literature concerning labor demand and specifically gross job flows has flourished during the past decade. Based largely upon the work of Davis and Haltiwanger (1990, 1992), Davis, Haltiwanger and Schuh (1996), and Dunne, Roberts and Samuelson (1989a), we know that there is tremendous heterogeneity in establishment level employment changes in the U.S. manufacturing sector. This is evident in the job creation and job destruction statistics underlying net employment growth. Beyond the extension to industries other than manufacturing, the results in this paper contribute to this literature by documenting how much of this heterogeneity is attributable to establishment births and deaths at different frequencies of measurement. This paper concludes with a discussion of how these results improve our understanding of topics such as the life cycle of establishments, employment stability, and the costs and inefficiencies associated with worker reallocation.

\section{The Data}

The Bureau of Labor Statistics (BLS) is currently constructing a longitudinal database that will contain quarterly employment and wage data for virtually all business establishments in the United States. This longitudinal database is designed to track changes in employment and wages not only at the macro level, but also at the micro level of the establishment. This database will be used to generate high quality, high frequency, timely and historically consistent information regarding job creation, job destruction, and the life cycle of establishments.

\section{IIa. Data Sources and Definitions}

The source of the establishment microdata used for constructing this new longitudinal database is the quarterly unemployment insurance microdata from the Bureau of Labor Statistics. All employers subject to state unemployment insurance (UI) laws are required to submit quarterly contribution reports detailing their monthly employment and quarterly wages to the State Employment Security Agencies (SESAs). After the microdata are edited and, if necessary, corrected by the State Labor Market Information staff, the states submit these data to the Bureau of Labor Statistics as part of the Covered Employment and Wages program (ES-202), which is a cooperative endeavor of BLS and the states. The data gathered in the ES-202 program are a comprehensive and accurate source of employment and wages, and provide a virtual census (98 percent) of employees on nonfarm payrolls. According to Employment and Wages, an annual publication of the BLS, employers in private industry in 1996 provided State Employment Security Agencies with quarterly UI tax reports for an average of 99.3 million wage and salary workers in 
approximately 6.9 million business establishments. ${ }^{3}$ For more information on the ES-202 program, see U.S. Bureau of Labor Statistics (1997) and Farmer and Searson (1995).

Several definitions deserve mention. An establishment is an economic unit, such as a factory or store, which produces goods or provides services. An establishment is usually a physical location and engaged in one or predominantly one type of economic activity for which a Standard Industrial Classification (SIC) code is applicable. The industry code of an establishment is assigned based on its primary activity, which is determined by the primary product or groups of products produced or distributed (or services rendered) by the establishment.

Employers report employment and wages on an individual establishment basis. Multiple Worksite Reports are used to collect separate employment and wage data for each establishment owned by employers with multiple locations within a state. The Multiple Worksite Reports were instituted as part of the Business Establishment List Improvement Project (BEL breakouts), which was a major initiative conducted jointly by the states and the Bureau of Labor Statistics in 1990 and 1991. The purpose of the BEL breakouts was to have businesses report their employment and wages at the establishment level rather than the reporting unit level that was used prior to the first quarter of 1991. Since the first quarter of 1991 (with the exception of two states that implemented the BEL breakouts in 1992), every multi-establishment employer with ten or more employees in secondary physical locations covered under one UI account has been requested (and in 21 states are legally required) to provide establishment level data.

Employment for a given month is the number of covered workers who earned wages during the pay period which includes the 12th of the month. The employment count includes all corporation officials, executives, other supervisory personnel, clerical workers, wage earners, persons on paid vacations or paid sick leave, pieceworkers, part-time workers, and workers earning wages which are nontaxable under UI because the taxable wage limit in the state has been exceeded. The employment count excludes workers who were on leave without pay or who earned no wages during the applicable pay period because of strikes, work stoppages, or temporary layoffs.

The quarterly UI microdata have information on monthly employment. In the empirical work to follow, I will use employment in the third month of the quarter as the measure of the establishment's quarterly employment. This is because comparisons between specific points in time are easier to interpret than are comparisons of quarterly averages. The averaging of monthly

${ }^{3}$ Excluded from private-sector coverage in 1996 were approximately 0.2 million wage and salary agricultural employees, 1.5 million self-employed farmers, 9.0 million self-employed nonagricultural workers, 0.6 million domestic workers, and 0.2 million unpaid family workers. In addition, with rules that vary by state, certain types of small nonprofit organizations are given a choice of coverage or exclusion. 
employment within a quarter distorts the timing of when changes in employment actually occurred, especially changes in employment that occur when an establishment shuts down. Furthermore, I will not report monthly employment flows constructed from data reported quarterly since these might be affected by unknown problems such as seam effects or other forms of recall bias. The quality of monthly employment flows in the UI data, both within and across quarters, is left for future research.

Davis, Haltiwanger, and Schuh (1996, Chapter 8.2) raise questions about the quality of using the ES-202 data for an analysis of job flows. They contend that UI reporting units do not correspond precisely to either establishments or enterprises, and businesses can and do change the level of aggregation at which they report information. This criticism is probably directed towards the data collected before the multiple worksite reports, and should not be an issue for the recent data reported at the establishment level. ${ }^{4}$ Since the introduction of the Multiple Worksite Reports in 1991, virtually all data are transmitted to BLS at the establishment level of reporting and are standardized with respect to content, structure, and BLS ES-202 definitions.

The UI microdata are unlikely to be contaminated by measurement error since these are administrative records used for tax purposes. However, the UI microdata are not without their faults. There is variation across states regarding who is covered by the UI system, since some states have expanded on the federal definition of coverage in order to include other workers. ${ }^{5}$ It is also difficult to identify corporate structures with the establishment level UI data, especially corporate structures that cross state boundaries. The researcher also needs to be aware of how states handle inactive accounts -- those UI accounts that have stopped reporting or continually report zero employment. This latter problem concerns how to use cross-sectional administrative data for longitudinal research purposes, and is the topic of section III of this paper.

\footnotetext{
${ }^{4}$ Multiple establishments can be nested within a UI account. Furthermore, several UI accounts can be nested within a legal entity, where a legal entity is defined by the Federal Employer Identification Number (EIN) as assigned by the Internal Revenue Service. It is well known that the concept of legal entities varies across multi-establishment employers as some employers may structure their corporate organizations in order to minimize their tax liabilities or other legal obligations. How the legal entity relates to economic entities is unclear. For this reason, all job flow statistics in this paper (and all job flow statistics forthcoming from BLS) will be calculated at the establishment level rather than the firm level.

5 The federal definition of coverage (with the exception of employers of agricultural labor and domestic service) applies to employers who during any calendar quarter in the current or immediately preceding calendar year paid wages of $\$ 1,500$ or more, or to employers of one or more workers on at least 1 day in each of 20 weeks during the current or immediately preceding calendar year.
} 


\section{IIb. Construction of Longitudinal Microdata}

There are two pieces of information in the ES-202 microdata that allow for matching establishments across quarters. The first is the SESA ID, which is the UI account number in combination with the establishment's reporting unit (RU) number. The SESA ID is the establishment's unique identifier that the State Employment Security Agencies transmit to BLS. Although the RU number is not used for administration of the unemployment insurance system, the RU number is assigned by the state (through information collected in the Multiple Worksite Reports) for BLS purposes of identifying establishments within a multi-establishment employer in that state. The SESA ID is specific to the business rather than specific to the location, which implies that if an establishment moves across the street in search of a bigger or better location, its SESA ID stays the same.

The second piece of information in the UI microdata used for longitudinal linking is the predecessor and successor numbers. The predecessor number is the SESA ID of the establishment that previously owned the establishment in the event of either a change in ownership or a change in reporting configuration (i.e. a breakout of units). The successor number is the SESA ID of the establishment that will take over the establishment in the event of either a change in ownership or a change in reporting configuration (i.e. a consolidation of units). The term "breakout" refers to a transition from a single establishment employer to a multi-establishment employer, and the term "consolidation" refers to a transition from a multi-establishment employer to a single establishment employer. These breakouts and consolidations may be actual economic events representing business expansions and contractions, or merely administrative reporting changes.

\section{IIc. Research Dataset}

The microdata used for the research in this paper are from the state of West Virginia from the first quarter of 1990 to the first quarter of 1995. As mentioned previously, the BEL breakouts were introduced in the first quarter of 1991, with two states being developed in 1992. However, eight states were reporting at the establishment level as of the first quarter of 1990, and using data from any of these eight states adds four extra quarters to the research data used in this project, thus maximizing the "T" in a panel of size NxT. Of these eight states, several were too small for meaningful analysis, and several were too large for my computing capabilities. West Virginia was the largest of the eight states that would fit within my computing capabilities.

Before linking the data across quarters, I excluded private household (SIC 8811), government, and agricultural establishments. I then matched the 21 consecutive quarters of West Virginia UI 
microdata (1990:1 to 1995:1) by SESA ID. ${ }^{6}$ On average, 93.4 percent of establishments in two consecutive quarters matched in this first step. Any establishment that did not match on SESA ID was then matched by predecessor and successor numbers. This second step matched approximately 8.3 percent of those eligible, thus resulting in an average quarterly match rate of 93.9 percent for establishments appearing in two consecutive quarters.

Finally, I will define four consecutive quarters of zero or imputed employment as a death. The motivation for this is to define births for those establishments that have a left censored stream of reported zero employment levels, and to define deaths for those establishments that have a right censored stream of reported zero employment levels. For example, in the West Virginia microdata, we observe 1123 establishments with at least four quarters of zero employment before the panel is right censored following the first quarter of 1995. It is reasonable to assume that these establishments died in early 1994 if not earlier. In order to implement this four quarter rule, we must delete the first and the last three quarters of the panel. The final longitudinal West Virginia dataset used in the job flows analysis has an average of approximately 35,000 establishments in each quarter from 1990:4 to 1994:2.

The longitudinal dataset used in the research reported here will not duplicate the data for West Virginia from the forthcoming BLS job flows dataset. The BLS is expanding on the matching algorithm described above and is implementing a probability based statistical match that attempts to identify two establishments with different SESA IDs as continuous. This probability based match compares births in the current quarter to deaths in the previous quarter and looks for occurrences such as the same name, the same address, and so forth. Robertson, Huff, Mikkelson, Pivetz, and Winkler (1997) provide a detailed description of the matching algorithm used for the forthcoming BLS longitudinal dataset, and present statistics which imply that any discrepancies between the forthcoming BLS data and the West Virginia research dataset used here will be small.

It is worth mentioning how the state of West Virginia during the early 1990s compares to the rest of the United States. Using data from Employment and Wages, the statistics presented in Table 1a indicate that there are no glaring differences between the U.S. economy and the West Virginia

\footnotetext{
${ }^{6}$ Because of the focus on births and deaths in this study, I have also matched the establishments by UI account number (ignoring the RU number in specific cases) to identify a small number of breakouts and consolidations not reported by predecessor or successor numbers. This is necessary because a RU number of 0 implies a single establishment employer, whereas a RU number of 1 or higher implies an establishment within a multi-unit employer. Thus, by definition, a single establishment that opens a new establishment or a multi establishment employer that closes all but one establishment will not match on SESA ID because the reporting unit numbers differ (from 0 to 1 or from 1 to 0 ). The number of observed transitions from single to multi-establishments and vice-versa within a UI account is less than 10 percent
} 
economy as measured by the 1994 point in time industry distributions of the number of establishments or the number of employees. For example, during 1994, the three largest industries as measured by the number of establishments in both the U.S. and in West Virginia are services, retail trade, and construction. The three largest industries as measured by employment in both the U.S. and in West Virginia are services, retail trade, and manufacturing. ${ }^{7}$

Of course, saying that the stock of establishments and/or employment in any given year in West Virginia is broadly representative of the U.S. economy is not equivalent to saying that the establishment and/or employment flows are representative. The net establishment flows between 1992 and 1994 and the net employment flows between 1992 and 1994 for West Virginia and the U.S. are given in Table 1b. We immediately see that the net employment growth rates during this time period are approximately 5.5 percent for both the U.S. as a whole and for West Virginia. However, the 4.5 percent net growth rate of the number of establishments in the U.S. is larger than the 2 percent growth rate in West Virginia. These statistics suggest that although the net job flows in West Virginia and in the U.S. are comparable, the establishment birth and death rates in West Virginia during the early 1990s might not be representative of the U.S. economy.

\section{An Empirical Definition of Births and Deaths}

In this section, we set forth the empirical definition of establishment births and deaths. Before turning to the data, does theory have anything to say about the definition of births and deaths? ${ }^{8}$ The issue here is that births and deaths are not identifiable events, but rather are processes of discrete steps such as the gestation period when the idea for a new business is formed, the formal application for UI eligibility, and the actual hiring of employees. Which of these discrete steps should be used as the empirical definition of births and deaths? As noted by Baldwin and Gorecki (1989) and Geroski (1991), an empirical definition of births and deaths depends on the particular context. For example, if we want to analyze short run job flows attributable to births and deaths,

of the number of births and deaths. I treat these establishments as breakouts and consolidations rather than as births and deaths in all tabulations.

7 The eight major industry groups used in this study are Mining (SIC 1000-1499), Construction (SIC 1500-1799), Manufacturing (SIC 2000-3999), Transportation and Public Utilities (SIC 4000-4999), Wholesale Trade (SIC 5000-5199), Retail Trade (SIC 5200-5999), Finance, Insurance, and Real Estate (SIC 6000-6799), and Services (SIC 7000-8999).

${ }^{8}$ As Hamermesh (1993) notes, "There is no standard textbook model of plant openings." Simple models of the representative firm, which were designed to estimate marginal employment effects using aggregate data, assume an existing and infinitely lived business, and implicit in these models is the concept of positive employment. Incorporating establishment births and deaths into these models would require explicitly taking account of behavior that occurs at the corner solution of an establishment's production function. 
this requires that births and deaths are defined as the first and last quarter of positive employment. On the other hand, an analysis of changes in the business environment with respect to competition or efficiency suggests that establishment births and deaths might be defined as changes in location, changes in primary economic activity, or changes in ownership.

This exercise of empirically defining births and deaths turns out to be a lesson in how to properly use cross-sectional administrative data for longitudinal research purposes. The UI microdata used here are collected for tax purposes and for cross-sectional statistical tabulations. Once the employer incurs the fixed cost of obtaining the UI account, there is no further cost to the employer other than time and postage when filing a quarterly contributions report. Therefore, it is not surprising that we observe many employers reporting zero employment for consecutive quarters. In any average quarter in the West Virginia microdata, 11.8 percent of establishments report zero employment. Initial occurrences of zero employment when the UI account first appears might occur if business owners apply for a UI account number before actually hiring their first employee. Terminal incidences of zero employment preceding the disappearance of the UI account number undoubtedly occur when an establishment reduces its employment level to zero while anticipating starting up the business again when economic conditions improve. When expectations imply re-opening the business rather than permanently closing the plant or the store, the establishment that has temporarily shut down may keep its UI account number active by reporting zero employment.

What is the incidence of delayed positive employment and zero employment preceding the disappearance of a SESA ID? In table 2a, I report the incidence of zero employment at birth for the universe of single establishments with a never before seen SESA ID (for the data used in this table, we have not yet defined four quarters of consecutive zero employment as a death). We see that 77.3 percent of these single establishment births have positive third month employment during their first quarter of reporting. Interestingly, 10.5 percent of single establishment births never have any positive third month employment before they either quit reporting or are right censored. Conditional on ever having positive employment, 13.7 percent of single establishment births have zero third month employment during their first quarter of reporting, and more than three-quarters (77.9 percent) of these establishments with zero employment in their first quarter have positive third month employment in their second quarter of reporting.

In table $2 \mathrm{~b}$, we analyze the incidence of zero employment at death for the newly appearing single establishment births that are also observed to disappear from the panel. Only 24.0 percent of these establishments have positive third month employment in their last quarter of reporting. Conditional on those establishments who had positive employment at some time, 66.8 percent have 
at least one quarter of zero third month employment preceding their disappearance. Only 47.9 percent of these establishments with terminal quarters of zero employment have just one quarter of zero employment preceding their disappearance, whereas 23.8 percent have two quarters of zero employment and 28.3 percent have three or more quarters of zero employment preceding their disappearance. In summary, initial occurrences of zero employment when an establishment appears for the first time are not uncommon, but are relatively rare compared to the large number of establishments with terminal quarters of zero employment before disappearing. ${ }^{9}$

Clearly, we do not want to define births and deaths as the appearance and disappearance of the SESA ID in this study. The consequence of doing so would be to bias downward the contribution of establishment births and deaths to job creation and job destruction, since the data in table 2 suggest that 23 percent of the births would be observed as an appearance with zero employment in the initial quarter, and 76 percent of the deaths would be observed as a disappearance with zero employment in the final quarter. Since we are interested in the jobs created and destroyed by establishment births and deaths, both in the short run and in the long run, we need to define births and deaths as the first and last quarter of positive employment.

Other than the obvious effect on job flows, does this definitional difference between the appearance and disappearance of the SESA ID versus the first and last quarter of positive employment matter? We evaluate this question by examining the hazard function for the time until death for the universe of single establishment births. The hazard functions for these data using both definitions of births and deaths are given in figure 1a, and the corresponding survivor functions are given in figure $1 \mathrm{~b} .{ }^{10}$ Although the shapes of survivor functions appear roughly similar with different

\footnotetext{
${ }^{9}$ I have also investigated the incidence of imputed employment at birth and death. There are three situations in which states impute employment data. First, if the quarterly contribution report is more than five months delinquent (which is when the states transmit the data to the BLS), employment is imputed. Employment can not be imputed in consecutive quarters for delinquent filers. Second, if the quarterly contribution report has been submitted with wage data but without employment data, and follow-up to obtain the missing employment data is not successful, then the employment data are imputed. Finally, if the quarterly contribution report has been completed and returned by a multi-establishment employer but the multiple worksite report has not been returned, the employment data for the individual establishments are imputed. In the entire West Virginia economy (and also for the sample of single establishment births), approximately 3 percent of all establishments have imputed employment. This figure is state specific, and other states may have higher or lower rates of employment imputation; the national average in the third quarter of 1995 is 10.1 percent. Accounting for the relatively few quarterly observations with initial and terminal imputed employment does not change the analysis in this section.

${ }^{10}$ Define $\mathrm{T}$ as a discrete random variable of failure times which take on the values $\mathrm{x}_{1}<\mathrm{x}_{2}<\ldots$ The hazard function is defined as $\lambda_{\mathrm{j}}=\operatorname{Prob}\left(\mathrm{T}=\mathrm{x}_{\mathrm{j}} \mid \mathrm{T} \geq \mathrm{x}_{\mathrm{j}}\right)$, which is interpreted as the probability of dying in a given quarter $\mathrm{j}$ conditional on surviving until that quarter. In the absence of covariates, the hazard function is estimated as $d_{j} / n_{j}$, where $d_{j}$ is the number of establishments who die at time $t_{j}$ and $n_{j}$ is the number of establishments alive and "at risk" for failure just prior to time $t_{j}$. The survivor function can be written as
} 
intercepts, the hazard functions are extremely different in the first three quarters. When births and deaths are defined as the appearance and disappearance of the SESA ID, the hazard increases between the first and third quarters (from 3.3 percent to 4.9 percent), and then begins a gradual decline. Note the spike in this hazard at eight months, which probably occurs when the state 'cleans' its files of establishments that have reported zero employment for eight consecutive quarters. The hazard function when births and deaths are defined as the first and last quarter of positive employment is monotonically declining. This hazard begins at 9.5 percent in the first quarter, and falls to 5.6 percent in the third quarter.

This difference between the monotonically declining hazard and the inverted-U shaped hazard in figure 1a has been discussed by both economists and those concerned with organizational demography. ${ }^{11}$ References for a monotonically declining hazard include Boeri and Bellmann (1995), Mata and Portugal (1994), and Mata, Portugal, and Guimarães (1995). References for an inverted-U shaped hazard include Brüderl and Schüssler (1990), Brüderl, Preisendörfer, and Ziegler (1992), Troske (1992), and Wagner (1994). ${ }^{12}$

Establishments undoubtedly experience their greatest difficulties as they learn about their business environment immediately following birth, and the shape of the hazard immediately following birth depends upon assumptions about how these establishments acquire information. If information about profitability takes time to acquire as it does in a Jovanovic (1982) model, then we should not observe any deaths until several realizations of information signal that shutting down the business is optimal. This occurs because the expected value of keeping the business open for several more quarters is positive, with the hope that the initial realization of information is a negative outlier with regard to the establishment's true unknown long run profitability. The rising portion of the inverted-U shaped hazard generated by this informational assumption has been referred to as the "honeymoon" period by Fichman and Levinthal (1991). On the other hand, if information about profitability is known immediately (or is revealed relatively quickly) after birth as assumed in

$\mathrm{F}(\mathrm{t})=\prod_{j \mid x_{j}<t}\left(1-\lambda_{j}\right)=\operatorname{Pr}\left(\mathrm{T} \geq \mathrm{x}_{\mathrm{j}}\right)$, which is interpreted as the probability of surviving until a given quarter $\mathrm{t}$. Note that the survivor function presents no new information beyond that conveyed by the hazard function. See Kalbfliesch and Prentice (1980) for a more complete discussion of hazard and survivor functions.

${ }^{11}$ Interestingly, the inverted-U shaped hazard function appears only in the quarterly hazards, but does not appear in the annual hazards. Computing annual hazards using first quarter (March) data, the hazard function when births and deaths are defined as the appearance and disappearance of the SESA ID is $\{.1218, .0785\}$ for the first two years (only two annual hazard points can be computed from the 1990:4 1994:2 data), and the hazard function using births and deaths defined as the first and last positive employment is $\{.1451, .0752\}$ for the first two years.

12 The hazard functions in Audretsch and Mahmood (1994), Baldwin and Gorecki (1991), and Pakes and Ericson (1998) can not be simply classified as either monotonically declining or inverted-U shaped. 
an Ericson and Pakes (1995) model, then we should observe a declining hazard as many businesses shut down immediately (or very soon) after opening.

The two hazard functions in figure 1a help to interpret and reconcile the competing theories. The data are consistent with a model where businesses respond to negative shocks by cutting employment to zero but keeping the business open in expectation of starting up again. The business then continues to acquire information about costs and output demand while not employing any labor, and then completely shuts down only after confirming the initial realization of nonprofitability. This can be seen clearly in figure 2 , where we see that re-defining death to be the last quarter of positive employment rather than the last appearance of the UI account causes the reversal of the slope of the hazard in the first several quarters after birth. Starting from the population of single establishment first births who have positive employment sometime during the panel (function \#2 with the "diamonds" in figure 2), we see that re-defining births to be the first quarter of positive employment essentially does nothing to the hazard (function \#2a with the "pluses" in figure 2), but re-defining deaths to be the last quarter of positive employment (function \#2b with the "squares" in figure 2) changes the slope of the hazard function during the first three quarters.

The informational theories described above are also consistent with theories of fixed costs. If shutting down the business involves fixed costs, which might occur if capital can only be sold at a discount from the original price, then this also increases the option value of keeping the business open for several more quarters. This implies that the hazard should vary based upon the amount of resources used in setting up the business. In figure 3, I present hazard functions based upon the initial size of the business, where initial size is defined as the number of employees in the first quarter of positive employment. The data are consistent with the fixed costs hypothesis, in that the hazard functions during the first several quarters are basically declining with initial size. We should also note that another explanation for the data in figure 3 is that a larger initial size might be a signal of greater confidence about survival.

\section{The Contribution of Births and Deaths to Employment Growth}

We now turn to the question of how establishment births and deaths contribute to job creation, job destruction, and net employment growth. Before turning to the empirical work, a brief review of how net employment growth can be decomposed into its underlying gross jobs flows is warranted. A comparison of cross-sectional employment at two points in time enables us to compute net employment growth: how many more jobs exist at the latter time period compared to the earlier time period. Thinking about how this net employment growth occurred, some 
establishments have expanded, some have contracted, and some establishments have either entered or exited the universe. Net employment growth is the number of jobs created by expanding and opening establishments minus the number of jobs destroyed by contracting and closing establishments. The jobs created by expanding and opening establishments are referred to as job creation, and the jobs destroyed by contracting and closing establishments are referred to as job destruction. $^{13}$

Formalizing this decomposition, we can write net employment growth as: ${ }^{14}$

$$
\left(\begin{array}{c}
\text { Net } \\
\text { Employment } \\
\text { Growth }
\end{array}\right)=\left(\begin{array}{c}
\text { Jobs } \\
\text { Created by } \\
\text { Births }
\end{array}\right)+\left(\begin{array}{c}
\text { Jobs } \\
\text { Created by } \\
\text { Expansions }
\end{array}\right)-\left(\begin{array}{c}
\text { Jobs } \\
\text { Destroyed by } \\
\text { Deaths }
\end{array}\right)-\left(\begin{array}{c}
\text { Jobs } \\
\text { Destroyed by } \\
\text { Contractions }
\end{array}\right) .
$$

Each of the terms on the right hand side can be expanded into a measure of establishment counts and a measure of the average number of jobs gained or lost per establishment. For example, the jobs created by births can be expressed as a function of the birth rate and the size of the average birth. Using this expansion, equation (1) can be rewritten as:

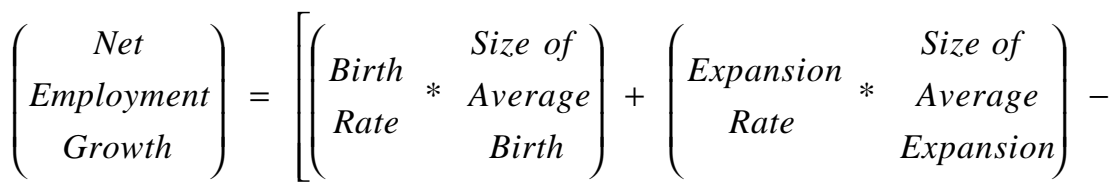

$$
\left.\left(\begin{array}{ccc}
\text { Death } & & \text { Size of } \\
\text { Rate } & * & \text { Average } \\
& & \text { Death }
\end{array}\right)-\left(\begin{array}{ccc}
\text { Contraction } & & \text { Size of } \\
\text { Rate } & & \text { Average } \\
& & \text { Contraction }
\end{array}\right)\right] *\left(\begin{array}{c}
\text { Total } \\
\text { Number of } \\
\text { Establishments }
\end{array}\right) .
$$

\footnotetext{
${ }^{13}$ It is important to note that although job creation and job destruction are powerful indicators of the underlying volatility in the demand side of the labor market, they do have their limitations. Job creation and job destruction are measures of the net jobs gained or lost at given establishments, and do not refer to the worker turnover within these establishments. The potential to analyze the relationship between job turnover and worker turnover is what makes a linked employer-employee database so appealing to economists.

${ }^{14}$ The jobs created and destroyed by breakouts and consolidations are omitted from this equation and from the following empirical work. The contribution of breakouts and consolidations to job creation, job destruction, and net employment growth is small relative to the contribution of births and deaths.
} 
The importance of the components on the right hand side of equation (2) will vary with the amount of time over which employment growth is measured. Most immediately, the birth and death rates will increase as we look over longer time horizons. We would also expect the average size of births and deaths to increase with the time horizon for several reasons. First, the universe of establishments changes over longer time periods as we select on surviving births and deaths of successful businesses. The average size of births and deaths will increase if transitory establishments that die shortly after birth are smaller than the average birth or death. Supporting evidence for this is given in figure 3, where larger establishment births have a higher probability of survival. Second, if employment growth in births is a gradual process as these new establishments learn about their business environment, then short run measures of employment growth will understate the amount of job creation attributable to births as these new establishments move towards their long run "equilibrium" employment levels. Similarly, if dying establishments lay-off their employees gradually over time, and leave a skeleton crew to "turn the lights off," then short run measures of job destruction will understate the jobs truly lost by these dying establishments.

Similar to the preceding argument, we would also expect the average size of expansions and contractions to increase with the time horizon. In the short run, since interviewing takes time and hiring for vacancies is not an immediate process, we would expect to see "structural" levels of job creation and destruction as certain jobs go unfilled for short durations of time. Short run measures of job creation and job destruction may also reflect seasonal employment patterns. Only in the long run will sustained expansions and contractions distinguish themselves from transitory employment fluctuations that are subsequently reversed in the short run.

Using data from West Virginia during the early 1990s, estimates for many of the components on the right hand side of equation (2) are presented in table 3. Estimates are provided on a quarterly frequency, an annual frequency, a biennial (two year) frequency, and a triennial (three year) frequency. For reasons described in the previous section of this paper, births are defined as the first quarter of positive employment and deaths are defined as the last quarter of positive employment.

On a quarterly basis, the average job creation rate is 8.37 percent and the average job destruction rate is 7.99 percent. ${ }^{15}$ These statistics imply that the amount of jobs created by births

${ }^{15}$ Notationally, let $\mathrm{E}_{\mathrm{t}}$ denote aggregate employment in quarter $\mathrm{t}$, let e index establishments, define $\mathrm{S}^{+}$as the sector of expanding and opening establishments, and define $\mathrm{S}^{-}$as the sector of contracting and closing establishments. The average quarterly net employment growth rate is written as

$$
\left(\frac{1}{14}\right)_{\mathrm{t}=91: 1}^{94: 2}\left[\frac{\mathrm{E}_{\mathrm{t}}-\mathrm{E}_{\mathrm{t}-1}}{\left\{\mathrm{E}_{\mathrm{t}}+\mathrm{E}_{\mathrm{t}-1}\right\} / 2}\right] \text {, }
$$


and expanding establishments in the average quarter amount to 8.4 percent of the total number of jobs, and the amount of jobs destroyed by deaths and contracting establishments in the average quarter amount to 8.0 percent of the total number of jobs. Differencing the job creation and job destruction rates, employment is growing on average at the rate of 0.38 percent per quarter (this is seen in the net employment growth rate in the bottom panel of table 3 ).

As shown by equation (2), job creation can be decomposed into a birth rate, an expansion rate, the average size of births, and the average size of an expansion. The quarterly birth rate is 3.53 percent, which is roughly seven times smaller than the quarterly expansion rate of 24.91 percent. Measured quarterly, the average size of a new establishment is 6.08 , whereas the average number of jobs added by an expanding establishment is 3.74. Although the number of jobs created by an average birth is larger than the number of jobs created by an average expansion when measured quarterly, the fact that expansions are much more prevalent than births at this frequency leads to the conclusion that births account for only 18.73 percent of jobs created on a quarterly basis. Similarly, establishment deaths account for 17.84 percent of jobs destroyed on a quarterly basis (these statistics are in the final columns of the top two panels of table 3).

The finding that establishment births and deaths only account for roughly 18 percent of job creation and job destruction might seem small, but it is important to recall that this is being measured on a quarterly frequency. As mentioned earlier, we would expect births and deaths to become more important as the timeframe of measurement increases. This is exactly what we see in the data. On an annual basis, establishment births account for 36.67 percent of jobs created, and establishment deaths account for 37.29 percent of jobs destroyed. These statistics increase to 49.59 percent and 53.39 percent, respectively, on a triennial basis. ${ }^{16}$ Therefore, when looking at

the average quarterly job creation rate is defined as

$$
\left(\frac{1}{14}\right) \sum_{t=91: 1}^{94: 2}\left[\sum_{e \in S^{+}}\left(\frac{E_{t}^{e}-E_{t-1}^{e}}{\left\{E_{t}+E_{t-1}\right\} / 2}\right)\right]=\left(\frac{1}{14}\right) \sum_{t=91: 1}^{94: 2}\left[\sum_{e \in S^{+}}\left(\frac{E_{t}^{e}-E_{t-1}^{e}}{\left\{E_{t}^{e}+E_{t-1}^{e}\right\} / 2}\right)\left(\frac{\left\{E_{t}^{e}+E_{t-1}^{e}\right\} / 2}{\left\{E_{t}+E_{t-1}\right\} / 2}\right)\right],
$$

and the average quarterly job destruction rate is defined as

$$
\left(\frac{1}{14}\right) \sum_{t=91: 1}^{94: 2}\left[\sum_{e \in S^{-}}\left(\frac{\left|E_{t}^{e}-E_{t-1}^{e}\right|}{\left\{E_{t}+E_{t-1}\right\} / 2}\right)\right]=\left(\frac{1}{14}\right) \sum_{t=91: 1}^{94: 2}\left[\sum_{e \in S^{-}}\left(\frac{\left|E_{t}^{e}-E_{t-1}^{e}\right|}{\left\{E_{t}^{e}+E_{t-1}^{e}\right\} / 2}\right)\left(\frac{\left\{E_{t}^{e}+E_{t-1}^{e}\right\} / 2}{\left\{E_{t}+E_{t-1}\right\} / 2}\right)\right] .
$$

As is evident in the above equations, I follow Davis, Haltiwanger, and Schuh (1996) by using the mean of employment in the current and the previous quarter when converting job change levels into rates.

16 The average annual net employment growth rate is written as

$$
\left(\frac{1}{11}\right) \sum_{t=91: 4}^{94: 2}\left[\frac{E_{t}-E_{t-4}}{\left\{E_{t}+E_{t-4}\right\} / 2}\right]
$$

the average biennial net employment growth rate is written as 
job flows over a long time horizon such as three years, establishment births account for half of all jobs created, and establishment deaths account for slightly more than half of all jobs destroyed.

This increasing importance of establishment births and deaths as we lengthen the time horizon over which employment growth is measured has also been found by Baldwin and Gorecki (1991). In their study, they find that the annual effects of firm entry and exit are relatively unimportant in the Canadian manufacturing sector, but when accumulated over six to eleven years, the effects of firm entry and exit are of considerable magnitude. I extend the analysis here and ask whether this increase is being driven by an increasing rate of births and deaths, or by an increasing average size of births and deaths. We see in table 3 that the birth rate grows from 3.53 percent on a quarterly basis to 27.34 percent on a triennial basis, and the death rate similarly grows from 3.17 percent to 23.97 percent. However, the size of the average birth grows only slightly from 6.08 measured quarterly to 7.70 measured triennially, and the average size of a death grows only slightly from 6.18 measured quarterly to 8.23 measured triennially. ${ }^{17}$ It would thus seem that the increasing importance of births and deaths as a source of job creation and job destruction is being driven by the rates rather than by the average size.

A formal decomposition analysis can inform us as to exactly how much of the increasing importance of births and deaths to job creation and job destruction as the time period of measurement increases is due to the rising birth and death rates. Define $R_{t}^{B}$ as the birth rate measured over the interval $\mathrm{t}$, and define $S_{t}^{B}$ as the size of the average birth measured over the interval t. Similarly, define $R_{t}^{E}$ as the expansion rate measured over the interval t, and define $S_{t}^{E}$

$$
\left(\frac{1}{7}\right)_{i=92: 4}^{94: 2}\left[\frac{E_{t}-E_{t-8}}{\left\{E_{t}+E_{t-8}\right\} / 2}\right]
$$

and the average triennial net employment growth rate is written as

$$
\left(\frac{1}{3}\right)_{t=93: 4}^{94: 2}\left[\frac{E_{t}-E_{t-12}}{\left\{E_{t}+E_{t-12}\right\} / 2}\right] \text {. }
$$

${ }^{17}$ It is important to note that triennial births are defined as all establishments in existence today that were not in existence three years ago, and triennial deaths are defined as all establishments in existence three years ago that are not in existence today. Therefore, the average size of births measured triennially is not the size of surviving establishments three years after their birth, but rather is a weighted average of the sizes of all establishments that did not exist three years previously. Similarly, the average size of deaths measured triennially is not the size of establishments three years before their death, but rather is a weighted average of the sizes of all establishments that will not exist three years from now.

I also note for completeness that the birth and expansion rates use the number of establishments in the current period as the denominator, whereas the death and contraction rates use the number of establishments in the previous period as the denominator. 
as the size of the average expansion measured over the interval $t$. The decomposition that we are interested in can be written as: ${ }^{18}$

$$
\begin{aligned}
&\left(\frac{R_{t}^{B} S_{t}^{B}}{R_{t}^{B} S_{t}^{B}+R_{t}^{E} S_{t}^{E}}\right)-\left(\frac{R_{t-1}^{B} S_{t-1}^{B}}{R_{t-1}^{B} S_{t-1}^{B}+R_{t-1}^{E} S_{t-1}^{E}}\right)=\left[\frac{\left(R_{t}^{B}-R_{t-1}^{B}\right) *\left(S_{t-1}^{B} R_{t-1}^{E} S_{t-1}^{E}\right)}{\left(R_{t}^{B} S_{t}^{B}+R_{t}^{E} S_{t}^{E}\right) *\left(R_{t-1}^{B} S_{t-1}^{B}+R_{t-1}^{E} S_{t-1}^{E}\right)}\right]+ \\
& {\left[\frac{\left(S_{t}^{B}-S_{t-1}^{B}\right) *\left(R_{t}^{B} R_{t-1}^{E} S_{t-1}^{E}\right)}{\left(R_{t}^{B} S_{t}^{B}+R_{t}^{E} S_{t}^{E}\right) *\left(R_{t-1}^{B} S_{t-1}^{B}+R_{t-1}^{E} S_{t-1}^{E}\right)}\right]+} \\
& {\left[\frac{-\left(R_{t}^{E}-R_{t-1}^{E}\right) *\left(R_{t-1}^{B} S_{t-1}^{B} S_{t-1}^{E}\right)}{\left(R_{t}^{B} S_{t}^{B}+R_{t}^{E} S_{t}^{E}\right) *\left(R_{t-1}^{B} S_{t-1}^{B}+R_{t-1}^{E} S_{t-1}^{E}\right)}\right]+} \\
& {\left[\frac{-\left(S_{t}^{E}-S_{t-1}^{E}\right) *\left(R_{t-1}^{B} S_{t-1}^{B} R_{t}^{E}\right)}{\left(R_{t}^{B} S_{t}^{B}+R_{t}^{E} S_{t}^{E}\right) *\left(R_{t-1}^{B} S_{t-1}^{B}+R_{t-1}^{E} S_{t-1}^{E}\right)}\right] . }
\end{aligned}
$$

The first term on the right hand side of the above equation is how much of the increase in the amount of job creation attributable to births as we increase the time period of measurement is attributable to the rising birth rates. The second term is how much is attributable to the increasing size of births, the third term is the contribution of the expansion rate, and the fourth term is the contribution of the increasing size of expansions. Note that the final two terms contain a negative sign, which indicates that as expansions become more important, births become less important.

The contributions of how rates and average sizes for both births and expansions affect the increase in the amount of job creation attributable to births as we increase the time period of measurement are presented in the top panel of table 4. The contributions are expressed as percentages, so that the four components add to 100 percent. For the comparison between quarterly and triennial frequencies (the third row of table 4), we see that the amount of job creation attributable to births increases by 30.89 percentage points (from 18.73 percent to 49.59 percent). The increase in birth rates from 3.53 percent on a quarterly basis to 27.34 percent on a triennial basis accounts for 89.76 percent of this increase. The increasing size of the average birth accounts for 27.46 percent, the increase in the expansion rate accounts for negative 2.08 percent, and the increasing size of expansions accounts for negative 15.14 percent. These statistics and the others in

18 There are multiple ways to write this decomposition. Intuitively, the difference $R_{t}^{B} S_{t}^{B}-R_{t-1}^{B} S_{t-1}^{B}$ can be written as both $R_{t}^{B}\left(S_{t}^{B}-S_{t-1}^{B}\right)+S_{t-1}^{B}\left(R_{t}^{B}-R_{t-1}^{B}\right)$ and $S_{t}^{B}\left(R_{t}^{B}-R_{t-1}^{B}\right)+R_{t-1}^{B}\left(S_{t}^{B}-S_{t-1}^{B}\right)$. I present estimates from one decomposition chosen randomly. Other decompositions that I have looked at yield similar estimates. 
the table indicate that the increasing birth rate is indeed mainly responsible for why births become an important source of job creation as the timeframe of measurement increases.

The analysis of how deaths contribute to job destruction in the bottom panel of table 4 tells the same story: the difference in death rates as we increase the time horizon is responsible for most of the increasing importance of deaths in the job destruction process. The conclusion to be drawn from tables 3 and 4 is that although the gradual growth or decline of establishments that are born or die is responsible for some of the increasing amount of job creation and job destruction attributable to births and deaths as we increase the timeframe of measurement, most of this increase appears to be due to the larger number of births and deaths observed in the long run.

We have seen that as the time horizon gets longer, the share of job creation attributable to births increases, and the share of job destruction attributable to deaths also increases. The natural question is to now ask about the share of net employment growth that is attributable to the combined effect of births and deaths. The calculations necessary to answer this question are presented in the bottom panel of table 3. The net employment growth rate, which is calculated as the difference between the job creation rate and the job destruction rate, can be decomposed into the sum of the net employment growth rate of births and deaths and the net employment growth rate of expansions and contractions.

We see in the bottom panel of table 3 that the net employment growth rate of establishment births and deaths is rising with the frequency of measurement. The net employment growth rate associated with births and deaths is 0.14 percent when measured on a quarterly basis, and is 1.61 percent when measured on a triennial basis. ${ }^{19}$ The net employment growth rate associated with expansions and contractions is also rising with the time horizon, and is roughly two to three times larger than the net employment growth rate of births and deaths at all frequencies of measurement. This leads us to conclude that the effect of births and deaths on the net employment growth rate, relative to the effect of expansions and contractions, is roughly constant over both short run and long run frequencies of measurement at a level where births and deaths account for roughly thirty percent of net employment growth.

How does this estimate compare to other estimates in the job flows literature? The estimates from table 2.1 and figure 2.3 of Davis, Haltiwanger and Schuh (1996) suggest that 67 percent of quarterly net employment growth and 79 percent of annual net employment growth in

19 The net employment growth rate of births and deaths is calculated as the job creation rate of births subtract the job destruction rate of deaths. For example, on a quarterly basis, the job creation rate of births is $1.57 \%(=8.37 * .1873$ from table 3$)$ and the job destruction rate of deaths is $1.43 \%(=7.99 * .1784$ 
manufacturing is attributable to the net effect of startups and shutdowns. ${ }^{20}$ In contrast, using a simple average over four quinquennial time periods, the statistics in table 1 of Dunne, Roberts and Samuelson (1989a) indicate that births and deaths account for 4 percent of net employment growth in manufacturing. The statistics from table 1 of Foote (1997) indicate that births and deaths account for 125 percent of annual net employment growth in Michigan, and Boeri and Cramer (1992) report that establishment births and deaths are responsible for 56 percent of annual net employment growth in the private German economy. The studies cited by Hamermesh (1993) and by Organisation for Economic Co-Operation and Development (1994) also exhibit widely varying estimates regarding how much of net employment growth can be attributed to establishment births and deaths. This divergence is in contrast to the relatively consistent finding across studies that establishment births and deaths are responsible for roughly one-third of annual gross job flows.

Finally, the job creation and job destruction statistics for each of the major industries are presented in table 5. The job creation rates in manufacturing at any frequency of measurement are the lowest of any industry. The quarterly job creation rate in manufacturing is 4.9 percent and the quarterly job destruction rate in manufacturing is 5.8 percent. These quarterly job creation and job destruction rates in manufacturing are similar to those reported by Davis, Haltiwanger, and Schuh (1996) -- 5.2 percent and 5.5 percent respectively, and are also similar to those reported by Anderson and Meyer (1995) -- 5.8 percent and 6.2 percent respectively. While we should not expect to replicate the job creation and job destruction rates found by these other studies, I find the similarity amazing in light of the different samples and the different time periods used in these various studies. ${ }^{21}$

One conclusion to take away from table 5 is that the job creation attributable to births and the job destruction attributable to deaths does not exhibit relatively large differences across industries.

from table 3). The net employment growth rate of births and deaths on a quarterly basis is thus $0.14 \%$ $(=1.57-1.43)$, which is the statistic in the bottom panel of table 3 .

20 The estimates from Davis and Haltiwanger $(1990,1992)$, which is based on a slightly different sample than Davis, Haltiwanger and Schuh (1996), suggests that 47 percent of annual net employment growth in manufacturing is attributable to the net effect of establishment births and deaths. This comparison illustrates the sensitivity of this calculation.

${ }^{21}$ We also see in table 5 that the job creation and job destruction rates in construction are larger than in most of the other industries. This was also found by Anderson and Meyer (1995) and Foote (1997). While the birth and death rates indicate that construction is a volatile industry, the quarterly job creation and job destruction rates are also affected by the large seasonality of employment in the construction industry. In the first and fourth quarters when construction employment declines, the quarterly job creation rate is roughly 16.6 percent and the quarterly job destruction rate is roughly 27.3 percent. In the second and third quarter when construction employment expands, the quarterly job creation rate is roughly 30.1 percent and the quarterly job destruction rate is roughly 14.7 percent. Many of the other industries exhibit seasonal variation in their quarterly employment levels, but not nearly as large (in percentage terms) as the seasonal variation in quarterly construction employment. 
For example, on a quarterly basis, the job creation attributable to births ranges from a low of 14 percent in services to a high of 23 percent in retail trade, and on a triennial basis, the job creation attributable to births ranges from a low of 41 percent in services to a high of 58 percent in mining, construction, and retail trade. Services also has one of the lowest percentages of job destruction attributable to deaths (13 percent measured quarterly and 47 percent measured on a triennial basis), whereas the highest percentage of job destruction attributable to deaths is in the manufacturing industry (27 percent measured quarterly and 59 percent measured on a triennial basis).

Interestingly, services has the highest net employment growth rate of any industry other than construction, and manufacturing has the lowest net employment growth rate of any industry other than mining. This leads us to ask whether there might be a negative correlation between the net employment growth rate and the percent of job destruction attributable to deaths. Using the eight major industries as our observations, the simple correlation between net employment growth and the percent of job destruction attributable to deaths is $-.76(\mathrm{p}=.03)$ on a quarterly basis, and is $-.58(\mathrm{p}=.13)$ on a triennial basis. When we weight each industry by its share of employment, the correlation is $-.84(\mathrm{p}=.01)$ measured quarterly and is $-.70(\mathrm{p}=.05)$ measured on a triennial basis. These correlations are presented in table 6 . Interestingly, the correlation between net employment growth and the percent of job creation attributable to births is much weaker than the correlation between net employment growth and the percent of job destruction attributable to deaths. This suggests that the severity of job destruction that is incorporated in establishment deaths might be a distinguishing factor of how growing industries differ from declining industries. While this hypothesis is purely speculative, further work at a finer industry level and taking advantage of the time-series variation within industries warrants further work.

\section{Conclusions and Discussion}

The motivation for this paper has been twofold. First, I introduce a new longitudinal dataset that is based upon establishment level unemployment insurance microdata. This dataset will be used by the Bureau of Labor Statistics to generate high quality, high frequency, timely and historically consistent information regarding job creation, job destruction, and the life cycle of establishments. This dataset has several advantages compared to other data used in the literature.

Most importantly, it is a quarterly census of essentially all establishments, both large and small, in all sectors of the economy. Having the universe of establishments is crucial to analyzing job flows; Boeri (1996) illustrates how the conclusions from this literature depend upon the industries and the sample selection of large versus small businesses used in the analysis. 
Second, I tackle the conceptual question of how to define establishment births and deaths. This turns out to be an exercise in how to properly use cross-sectional administrative data for longitudinal research purposes. I have found that definitions matter, as illustrated by the analysis of hazard functions using two alternative definitions of births and deaths. The difference between the monotonically declining hazard and the inverted-U shaped hazard helps us interpret the informational assumptions inherent in competing theories of business birth, their growth, and their survival. Specifically, the data are consistent with a model where businesses respond to negative shocks by cutting employment to zero while continuing to acquire information about costs and output demand, and then completely shut down several quarters later after confirming their initial realization of non-profitability.

Much of the analysis in this paper has concentrated on examining how establishment births and deaths influence job creation, job destruction, and net employment growth. The innovation of the research reported here has been to examine the job flows measured over various time horizons. I have found that at a quarterly frequency, births and deaths account for less than one-fifth of job creation and job destruction, and over a one year period, more than one-third of all job creation and job destruction is through establishment births and deaths. At a triennial frequency, births and deaths account for half of all jobs created and destroyed. The driving force behind this increasing importance of births and deaths in the long run is not so much the gradual growth or decline of establishments that are born or die, but rather a rate of establishment births and deaths that rises from 3 percent quarterly to 25 percent triennially. The magnitude of these establishment birth and death rates, and the job flows resulting from these births and deaths, reinforces the conventional wisdom that simple models of a representative infinitely lived business with positive employment can not account for observed employment dynamics.

Perhaps the main theme running through this paper has been that of labor market churning. We know from previous work that aggregate changes in employment are characterized by large amounts of underlying volatility. For example, at the level of the individual, the total number of persons who currently have a different job or employment status than they had twelve months earlier equals 36.8 percent of employment (Davis and Haltiwanger 1995). At the level of the establishment, 20 percent of manufacturing jobs have either been destroyed or created over a one year interval. The empirical work in this paper expands our understanding of the sources of heterogeneity in employment stability by documenting that births and deaths do matter when studying job flows.

The role of establishment births and deaths as a source of labor market churning has implications for our understanding of both labor and industrial economics. For example, the finding 
that half of all jobs destroyed in a three year period are due to the death of establishments highlights the permanence of this job loss. The literature on displaced workers, which implicitly assumes that wages grow with tenure, suggests large costs to workers impacted by the death of an establishment. Furthermore, the finding that 40 percent of new businesses die within three years of their birth illustrates the transitory nature of many of these establishments and the jobs they create. In light of the prediction from the specific human capital model that both workers and firms lose when a match dissolves, the highly transitory nature of many (but not all) of the employment opportunities offered by establishment births is suggestive of substantial costs and inefficiencies in the labor market. Such a conclusion is also reached by matching models which recognize that search is costly to both the worker and the firm.

To conclude this paper, we should distinguish between what we have and have not attempted to do in this paper. The empirical work in this paper has been primarily descriptive as a means of introducing and highlighting the new establishment level UI dataset. Although the work in this paper is very similar to the large literature on analyzing the life cycle of firms, especially the survival and growth of establishment births, I have not pretended to replicate the work in this literature by authors such as Baldwin and Gorecki (1991), Boeri and Cramer (1992), Dunne, Roberts, and Samuelson (1989b), Evans (1987a, 1987b), and Hall (1987). This study has also not attempted any analysis of job flows at various stages of the business cycle. The West Virginia economy had declining employment levels between 1990 and 1991, followed by employment levels that rose by an annual average rate of 2.7 percent between 1992 and 1994. In light of the finding that job destruction may or may not be an indicator of the business cycle, an exploration of job flows over the business cycle, especially the job flows associated with births and deaths, would be an interesting exercise with these data. In combination with the detailed geographical detail that is contained in the microdata, we could also attempt to study the incidence of births and deaths in relation to the business cycle holding constant characteristics of the local labor market such as average wages and industrial concentration. This is merely a short list of research topics that can be addressed with the new UI establishment based longitudinal microdata. 


\section{References}

Anderson, Patricia M. and Bruce D. Meyer. 1994. "The Extent and Consequences of Job Turnover." Brookings Papers on Economic Activity, pp. 177-236.

Audretsch, David B. and Talat Mahmood. 1994. "The Rate of Hazard Confronting New Firms and Plants in U.S. Manufacturing." Review of Industrial Organization, pp. 41-56.

Baldwin, John R. and Paul K. Gorecki. 1989. "Measuring Firm Entry and Exit With Panel Data." Proceedings of the Statistics Canada Symposium on Analysis of Data in Time.

Baldwin, John R. and Paul K. Gorecki. 1991. "Firm Entry and Exit in the Canadian Manufacturing Sector, 1970-1982." Canadian Journal of Economics, pp. 300-323.

Boeri, Tito. 1996. "Is Job Turnover Countercyclical?" Journal of Labor Economics, pp. 603-625.

Boeri, Tito and Lutz Bellmann. 1995. "Post-entry Behaviour and the Cycle: Evidence from Germany.” International Journal of Industrial Organization, pp. 483-500.

Boeri, Tito and Ulrich Cramer. 1992. "Employment Growth, Incumbents, and Entrants." International Journal of Industrial Organization, pp. 545-565.

Brüderl, Josef and Rudolf Schüssler. 1990. "Organizational Mortality: The Liabilities of Newness and Adolescence.” Administrative Science Quarterly, pp. 530-547.

Brüderl, Josef, Peter Preisendörfer, and Rolf Ziegler. 1992. "Survival Chances of Newly Founded Business Organizations." American Sociological Review, pp. 227-242.

Davis, Steven J. and John C. Haltiwanger. 1990. "Gross Job Creation and Destruction: Microeconomic Evidence and Macroeconomic Implications." NBER Macroeconomics Annual, pp. 123-168.

Davis, Steven J. and John C. Haltiwanger. 1992. "Gross Job Creation, Gross Job Destruction, and Employment Reallocation." Quarterly Journal of Economics, pp. 819-863.

Davis, Steven J. and John C. Haltiwanger. 1995. "Measuring Gross Worker and Job Flows." NBER Working Paper \#5133.

Davis, Steven J., John C. Haltiwanger, and Scott Schuh. 1993. "Small Business and Job Creation: Dissecting the Myth and Reassessing the Facts." NBER Working Paper \#4492.

Davis, Steven J., John C. Haltiwanger, and Scott Schuh. 1996. Job Creation and Destruction. MIT Press.

Dunne, Timothy, Mark J. Roberts, and Larry Samuelson. 1988. "Patterns of Firm Entry and Exit in U.S. Manufacturing Industries." Rand Journal of Economics, pp. 495-515. 
Dunne, Timothy, Mark J. Roberts, and Larry Samuelson. 1989a. "Plant Turnover and Gross Employment Flows in the U.S. Manufacturing Sector." Journal of Labor Economics, pp. 48-71.

Dunne, Timothy, Mark J. Roberts, and Larry Samuelson. 1989b. "The Growth and Failure of U.S. Manufacturing Plants.” Quarterly Journal of Economics, pp. 671-698.

Ericson, Richard and Ariel Pakes. 1995. "Markov-Perfect Industry Dynamics: A Framework for Empirical Work." Review of Economic Studies, pp. 53-82.

Evans, David S. 1987a. "Tests of Alternative Theories of Firm Growth.” Journal of Political Economy, pp. 657-674.

Evans, David S. 1987b. "The Relationship Between Firm Growth, Size, and Age: Estimates for 100 Manufacturing Industries." Journal of Industrial Economics, pp. 567-581.

Farmer, Tracy E. and Michael A. Searson. 1995. "Use of Administrative Records in the Bureau of Labor Statistics' Covered Employment and Wages (ES-202) Program." Proceedings of the Bureau of the Census 1995 Annual Research Conference, pp. 198-235.

Fichman, Mark and Daniel A. Levinthal. 1991. "Honeymoons and the Liability of Adolescence: A New Perspective on Duration Dependence in Social and Organizational Relationships." Academy of Management Review, pp. 442-468.

Foote, Christopher L. 1997. "Trend Employment Growth and the Bunching of Job Creation and Destruction." Unpublished paper, Harvard University.

Geroski, P.A. 1991. Market Dynamics and Entry. Basil Blackwell Ltd.

Hamermesh, Daniel S. 1993. Labor Demand. Princeton University Press.

Hall, Bronwyn H. 1987. "The Relationship Between Firm Size and Firm Growth in the U.S. Manufacturing Sector.” Journal of Industrial Economics, pp. 583-606.

Jovanovic, Boyan. 1982. "Selection and the Evolution of Industry." Econometrica, pp. 649-670.

Kalbfliesch, J.D. and R.L. Prentice. 1980. The Statistical Analysis of Failure Time Data. John Wiley and Sons, New York.

Lane, Julia, David Stevens, and Simon Burgess. 1996. "Worker and Job Flows.” Economics Letters, pp. 109-114.

Leonard, Jonathan S. 1987. "In the Wrong Place at the Wrong Time: The Extent of Frictional and Structural Unemployment." Unemployment and The Structure of Labor Markets, Kevin Lang and Jonathan S. Leonard, editors, pp. 141-163.

Mata, José and Pedro Portugal. 1994. "Life Duration of New Firms." The Journal of Industrial Economics, pp. 227-245.

Mata, José, Pedro Portugal, and Paulo Guimarães. 1995. "The Survival of New Plants: Start-up Conditions and Post-Entry Evolution." International Journal of Industrial Organization, 
pp. $459-481$.

Organisation for Economic Co-Operation and Development. 1994. Employment Outlook.

Pakes, Ariel and Richard Ericson. 1998. "Empirical Implications of Alternative Models of Firm Dynamics." Forthcoming, Journal of Economic Theory.

Robertson, Kenneth, Larry Huff, Gordon Mikkelson, Timothy Pivetz, and Alice Winkler. 1997. "Improvements in Record Linkage Processes for the Bureau of Labor Statistics' Business Establishment List." Forthcoming, Proceedings for the 1997 Record Linkage Workshop and Exposition.

Troske, Kenneth Robert. 1992. "The Growth and Survival of Firms and Changes in the Firm Size Distribution in Industries." Ph.D. Dissertation, University of Chicago.

Wagner, Joachim. 1994. "The Post-Entry Performance of New Small Firms in German Manufacturing Industries." The Journal of Industrial Economics, pp. 141-154.

U.S. Bureau of Labor Statistics, 1997. BLS Handbook of Methods, Bulletin \#2490. 
Table 1a: Comparison of U.S. and West Virginia Number of Establishments and Number of Employees, 1994 Source: Employment and Wages

\begin{tabular}{l|cc|cc|} 
& \multicolumn{2}{|c|}{ Average Establishments } & \multicolumn{2}{c|}{ Annual Average Employment } \\
& \multicolumn{2}{|c}{ West } & \multicolumn{2}{c|}{ West } \\
& U.S. & Virginia & U.S. & Virginia \\
\hline Mining & $0.47 \%$ & $2.67 \%$ & $0.65 \%$ & $5.44 \%$ \\
Construction & $10.29 \%$ & $12.79 \%$ & $5.32 \%$ & $6.69 \%$ \\
Manufacturing & $6.24 \%$ & $4.68 \%$ & $19.82 \%$ & $15.97 \%$ \\
Transportation \& Public Utilities & $4.29 \%$ & $5.99 \%$ & $6.21 \%$ & $7.08 \%$ \\
Wholesale Trade & $9.66 \%$ & $8.85 \%$ & $6.66 \%$ & $5.83 \%$ \\
Retail Trade & $22.19 \%$ & $24.83 \%$ & $22.18 \%$ & $24.18 \%$ \\
Finance, Insurance, \& Real Estate & $9.11 \%$ & $7.78 \%$ & $7.26 \%$ & $4.87 \%$ \\
Services & $37.75 \%$ & $32.40 \%$ & $31.91 \%$ & $29.94 \%$ \\
\hline Total & $\mathrm{N}=6,371,103$ & $\mathrm{~N}=41,315$ & $\mathrm{~N}=92,410,522$ & $\mathrm{~N}=512,616$
\end{tabular}

Table 1b: Comparison of U.S. and West Virginia Growth Rates, Number of Establishments and Number of Employees, 1992-1994 Source: Employment and Wages

\begin{tabular}{l|cc|cc|} 
& \multicolumn{2}{|c|}{ Average Establishments } & \multicolumn{2}{c|}{ Annual Average Employment } \\
& \multicolumn{2}{|c}{ West } & \multicolumn{2}{c|}{ West } \\
& U.S. & Virginia & U.S. & Virginia \\
\hline Mining & $-5.62 \%$ & $-11.13 \%$ & $-5.24 \%$ & $-10.80 \%$ \\
Construction & $3.60 \%$ & $9.81 \%$ & $10.45 \%$ & $23.87 \%$ \\
Manufacturing & $3.08 \%$ & $2.66 \%$ & $1.37 \%$ & $-0.35 \%$ \\
Transportation \& Public Utilities & $7.42 \%$ & $6.08 \%$ & $5.37 \%$ & $4.86 \%$ \\
Wholesale Trade & $2.75 \%$ & $-4.79 \%$ & $1.58 \%$ & $-1.18 \%$ \\
Retail Trade & $2.55 \%$ & $-0.72 \%$ & $5.64 \%$ & $6.99 \%$ \\
Finance, Insurance, \& Real Estate & $6.76 \%$ & $2.42 \%$ & $3.80 \%$ & $3.30 \%$ \\
Services & $5.81 \%$ & $3.73 \%$ & $8.28 \%$ & $10.23 \%$ \\
\hline Total & $4.46 \%$ & $2.04 \%$ & $5.31 \%$ & $5.65 \%$
\end{tabular}


Table 2a: The Incidence of Zero Employment at Birth Single Establishment First Births, Unadjusted Data West Virginia Longitudinal ES-202 Microdata, 1990:4-1994:2

\begin{tabular}{l|r|r|r|r|}
\begin{tabular}{l|r|r} 
Number of Quarters After Birth \\
Until Positive Employment
\end{tabular} & Frequency & Percent & $\begin{array}{r}\text { Conditional } \\
\text { Percent }^{1}\end{array}$ & $\begin{array}{r}\text { Conditional } \\
\text { Percent }^{2}\end{array}$ \\
\hline 0 (Positive Employment at Birth) & 11,625 & $77.3 \%$ & $86.3 \%$ & \\
1 & 1,433 & $9.5 \%$ & $10.6 \%$ & $77.9 \%$ \\
2 & 220 & $1.5 \%$ & $1.6 \%$ & $12.0 \%$ \\
3 & 84 & $0.6 \%$ & $0.6 \%$ & $4.6 \%$ \\
4 & 46 & $0.3 \%$ & $0.3 \%$ & $2.5 \%$ \\
5 & 19 & $0.1 \%$ & $0.1 \%$ & $1.0 \%$ \\
6 & 17 & $0.1 \%$ & $0.1 \%$ & $0.9 \%$ \\
7 & 11 & $0.1 \%$ & $0.1 \%$ & $0.6 \%$ \\
8 & 7 & $0.1 \%$ & $0.1 \%$ & $0.4 \%$ \\
9 & 2 & $0.0 \%$ & $0.0 \%$ & $0.1 \%$ \\
10 & 0 & $0.0 \%$ & $0.0 \%$ & $0.0 \%$ \\
11 & 0 & $0.0 \%$ & $0.0 \%$ & $0.0 \%$ \\
12 & 0 & $0.0 \%$ & $0.0 \%$ & $0.0 \%$ \\
13 & 0 & $0.0 \%$ & $0.0 \%$ & $0.0 \%$ \\
Never any Positive Employment & 1,577 & $10.5 \%$ & & \\
\hline
\end{tabular}

Table 2b: The Incidence of Zero Employment at Death Single Establishment First Births, Unadjusted Data West Virginia Longitudinal ES-202 Microdata, 1990:4-1994:2

\begin{tabular}{|c|c|c|c|c|}
\hline $\begin{array}{l}\text { Number of Quarters with Zero } \\
\text { Employment Preceding Death }\end{array}$ & Frequency & Percent & $\begin{array}{r}\text { Conditional } \\
\text { Percent }^{1} \\
\end{array}$ & $\begin{array}{r}\text { Conditional } \\
\text { Percent }^{2} \\
\end{array}$ \\
\hline 0 (Positive Employment at Death) & 885 & $24.0 \%$ & $33.2 \%$ & \\
\hline 1 & 852 & $23.1 \%$ & $32.0 \%$ & $47.9 \%$ \\
\hline 2 & 423 & $11.5 \%$ & $15.9 \%$ & $23.8 \%$ \\
\hline 3 & 181 & $4.9 \%$ & $6.8 \%$ & $10.2 \%$ \\
\hline 4 & 108 & $2.9 \%$ & $4.1 \%$ & $6.1 \%$ \\
\hline 5 & 48 & $1.3 \%$ & $1.8 \%$ & $2.7 \%$ \\
\hline 6 & 37 & $1.0 \%$ & $1.4 \%$ & $2.1 \%$ \\
\hline 7 & 19 & $0.5 \%$ & $0.7 \%$ & $1.1 \%$ \\
\hline 8 & 64 & $1.7 \%$ & $2.4 \%$ & $3.6 \%$ \\
\hline 9 & 43 & $1.2 \%$ & $1.6 \%$ & $2.4 \%$ \\
\hline 10 & 3 & $0.1 \%$ & $0.1 \%$ & $0.2 \%$ \\
\hline 11 & 1 & $0.0 \%$ & $0.0 \%$ & $0.1 \%$ \\
\hline 12 & 0 & $0.0 \%$ & $0.0 \%$ & $0.0 \%$ \\
\hline \multirow[t]{2}{*}{ Never any Positive Employment } & 1,026 & $27.8 \%$ & & \\
\hline & 3,690 & & & \\
\hline
\end{tabular}


Figure 1a: Quarters Until Death Empirical Hazard

Single Establishment First Births

West Virginia Longitudinal ES-202 Microdata, 1990:4-1994:2

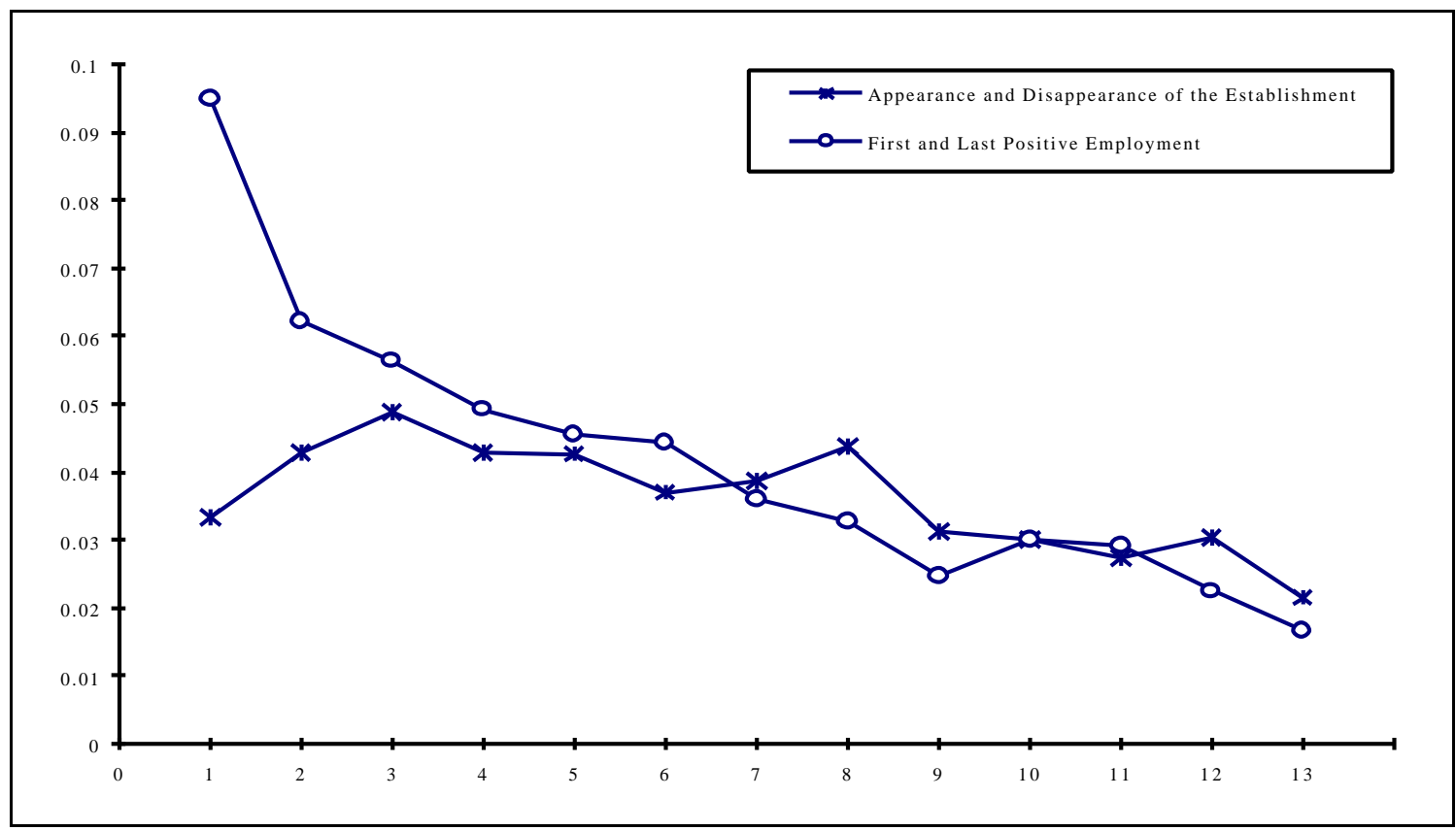

Hazard $(\mathrm{t})=\operatorname{Prob}($ death $\mathrm{t}$ quarters after birth $\mid$ death at or later than $\mathrm{t}$ quarters after birth)s

Figure 1b: Quarters Until Death Empirical Survivor Function Single Establishment First Births

West Virginia Longitudinal ES-202 Microdata, 1990:4-1994:2

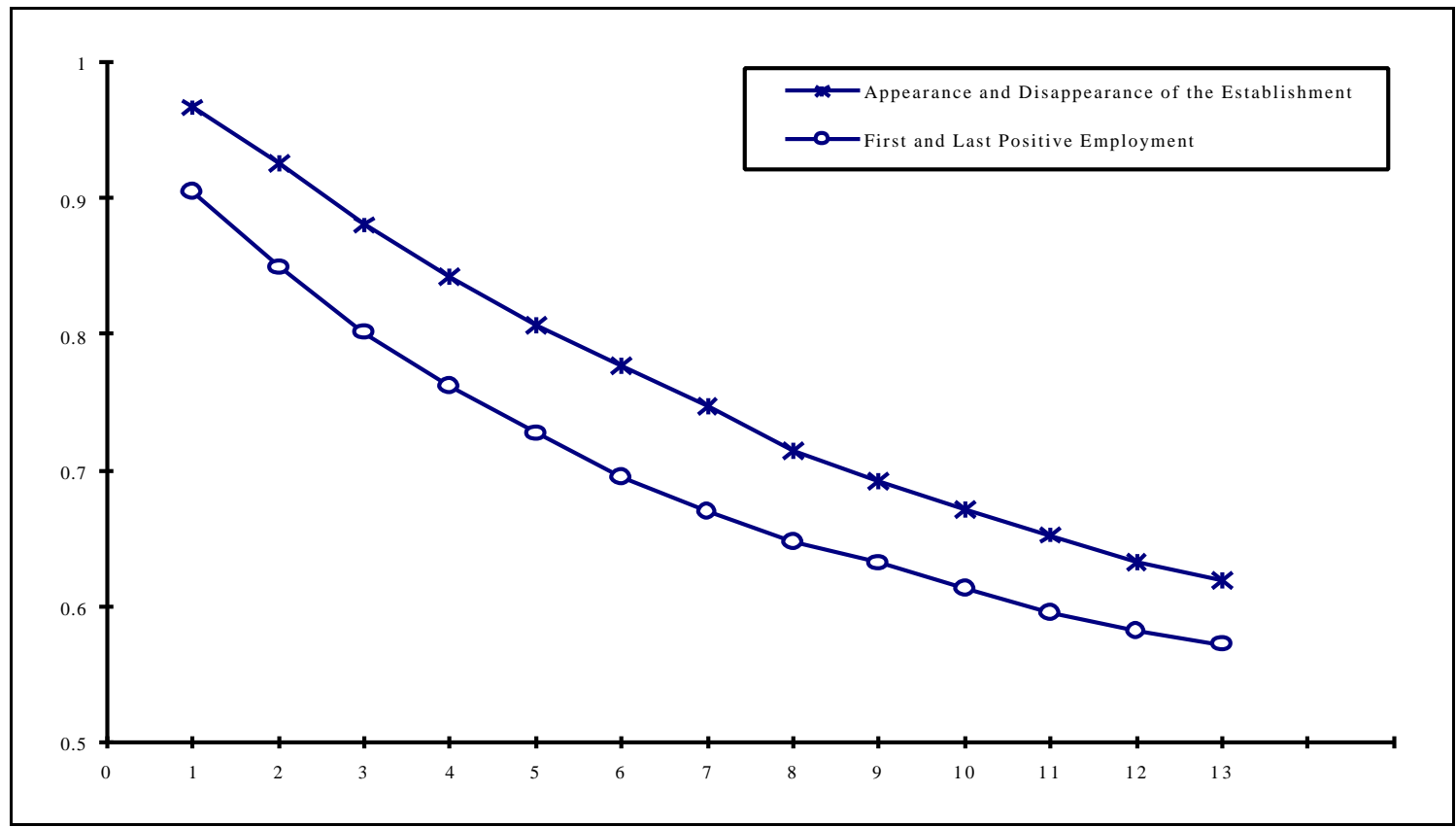

Survivor Function $(\mathrm{t})=$ Prob(death $\mathrm{t}$ quarters or later after birth) 
Figure 2: Quarters Until Death Empirical Hazard

Single Establishment First Births

West Virginia Longitudinal ES-202 Microdata, 1990:4-1994:2

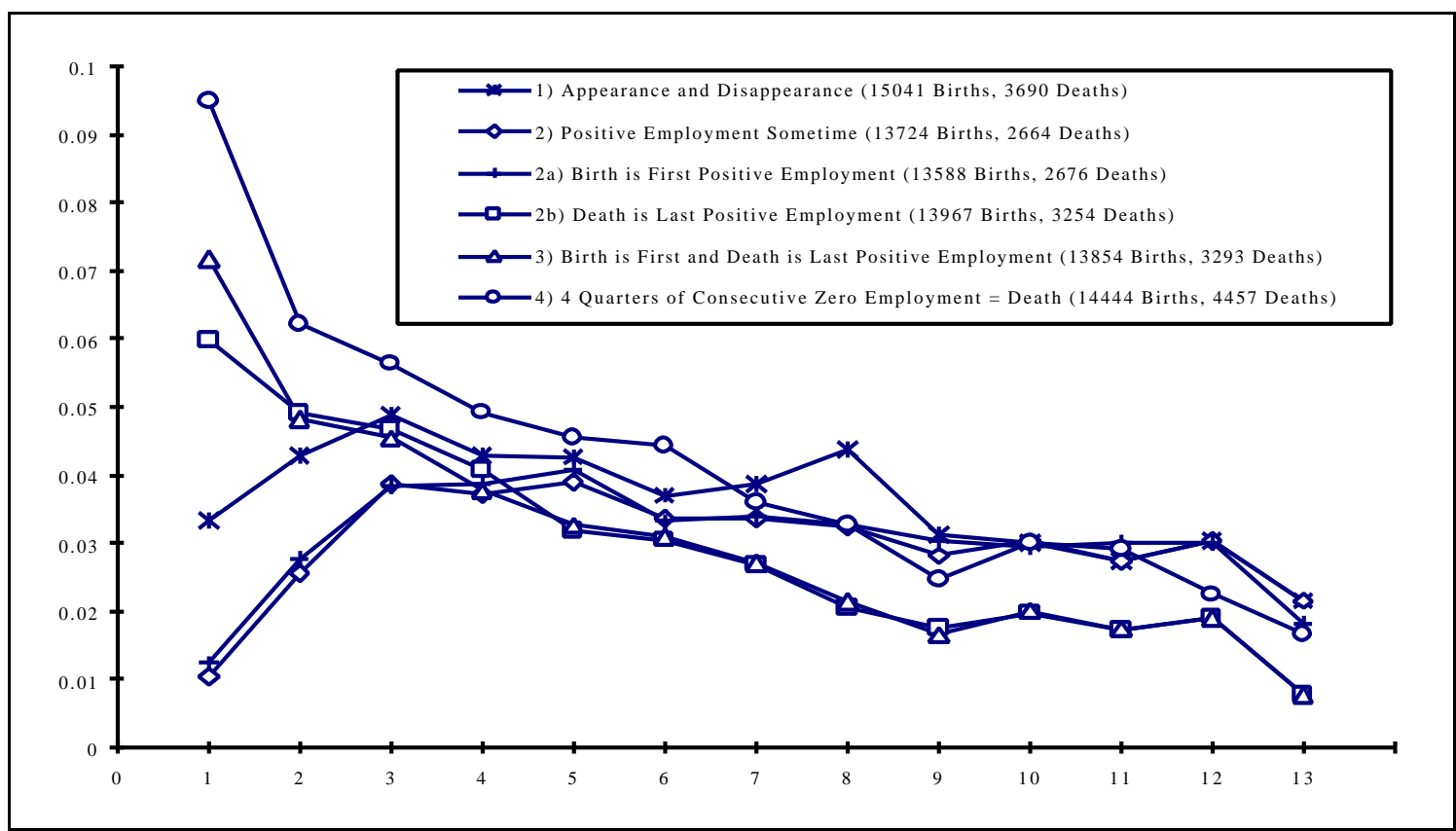

Hazard $(\mathrm{t})=$ Prob(death $\mathrm{t}$ quarters after birth $\mid$ death at or later than $\mathrm{t}$ quarters after birth) 
Figure 3: Quarters Until Death Empirical Hazard, by Employment at Birth Single Establishment First Births (First and Last Positive Employment) West Virginia Longitudinal ES-202 Microdata, 1990:4-1994:2
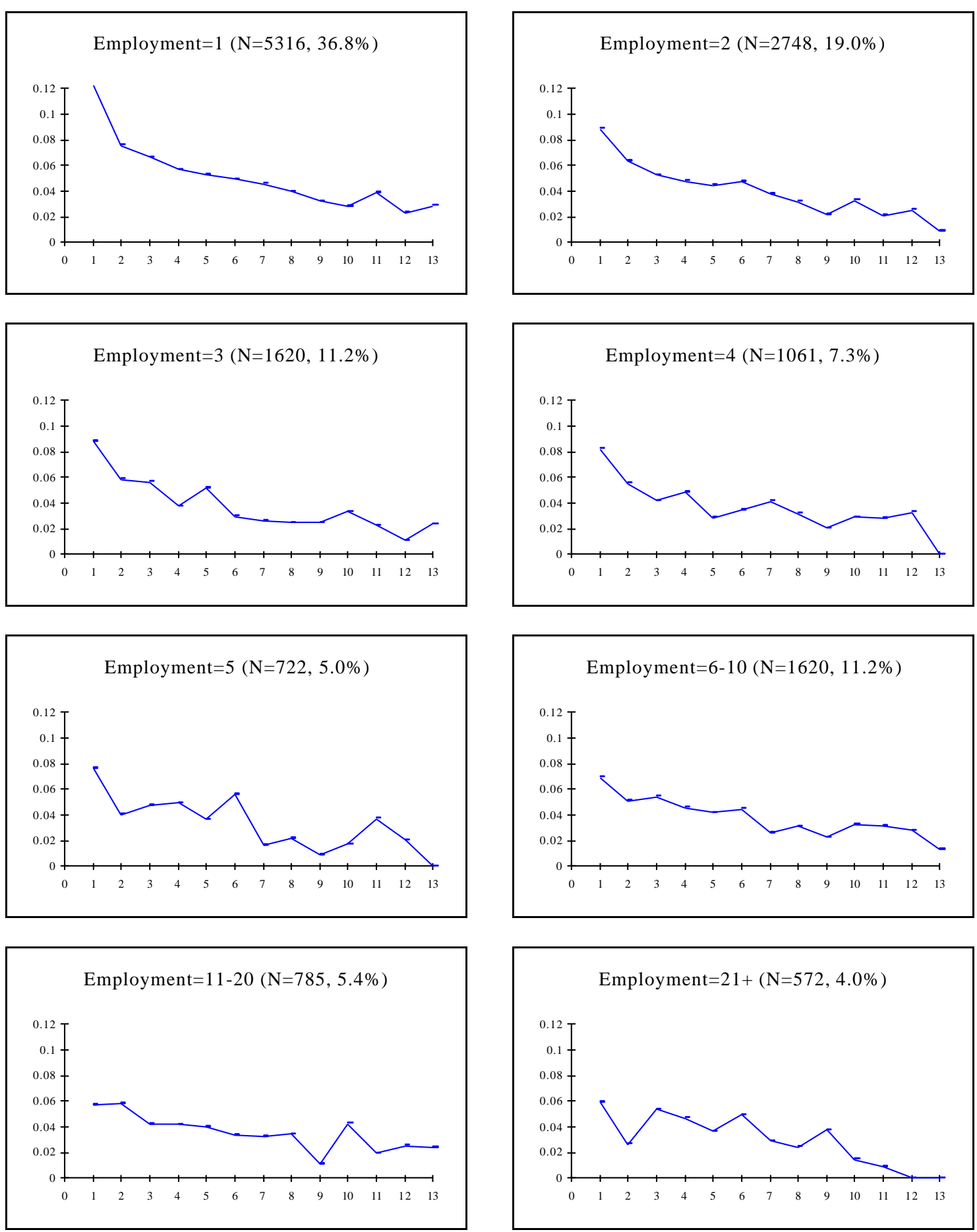

Hazard $(t)=\operatorname{Prob}($ death $t$ quarters after birth $\mid$ death at or later than $t$ quarters after birth) 
Table 3: Job Creation, Job Destruction, and Net Employment Growth West Virginia Longitudinal ES-202 Microdata, 1990:4-1994:2

\begin{tabular}{l|c|c|c|c|c|c|} 
& $\begin{array}{c}\text { Job } \\
\text { Creation } \\
\text { Rate }\end{array}$ & $\begin{array}{c}\text { Birth } \\
\text { Rate }\end{array}$ & $\begin{array}{c}\text { Size of } \\
\text { Average } \\
\text { Birth }\end{array}$ & $\begin{array}{c}\text { Expansion } \\
\text { Rate }\end{array}$ & $\begin{array}{c}\text { Sob } \\
\text { Average } \\
\text { Expansion }\end{array}$ & $\begin{array}{c}\text { Creation } \\
\text { Attributable } \\
\text { to Births }\end{array}$ \\
\hline Quarterly & $8.37 \%$ & $3.53 \%$ & 6.08 & $24.91 \%$ & 3.74 & $18.73 \%$ \\
Annual & $15.82 \%$ & $12.07 \%$ & 6.54 & $28.51 \%$ & 4.78 & $36.67 \%$ \\
Biennial & $24.22 \%$ & $20.67 \%$ & 7.02 & $29.35 \%$ & 6.20 & $44.39 \%$ \\
Triennial & $31.32 \%$ & $27.34 \%$ & 7.70 & $28.81 \%$ & 7.42 & $49.59 \%$ \\
\hline
\end{tabular}

\begin{tabular}{l|c|c|c|c|c|c|} 
& $\begin{array}{c}\text { Job } \\
\text { Destruction } \\
\text { Rate }\end{array}$ & $\begin{array}{c}\text { Death } \\
\text { Rate }\end{array}$ & $\begin{array}{c}\text { Size of } \\
\text { Average } \\
\text { Death }\end{array}$ & $\begin{array}{c}\text { Contraction } \\
\text { Rate }\end{array}$ & $\begin{array}{c}\text { Size of } \\
\text { Average } \\
\text { Contraction }\end{array}$ & $\begin{array}{c}\text { Destruction } \\
\text { Attributable } \\
\text { to Deaths }\end{array}$ \\
\hline Quarterly & $7.99 \%$ & $3.17 \%$ & 6.18 & $24.14 \%$ & 3.74 & $17.84 \%$ \\
Annual & $14.42 \%$ & $10.56 \%$ & 7.04 & $26.36 \%$ & 4.74 & $37.29 \%$ \\
Biennial & $21.03 \%$ & $17.78 \%$ & 7.82 & $26.09 \%$ & 5.94 & $47.29 \%$ \\
Triennial & $26.08 \%$ & $23.97 \%$ & 8.23 & $25.26 \%$ & 6.82 & $53.39 \%$ \\
\hline
\end{tabular}

\begin{tabular}{l|c|c|c|c|} 
& $\begin{array}{c}\text { Net Employment } \\
\text { Growth Rate }\end{array}$ & $\begin{array}{c}\text { Net Employment } \\
\text { Growth Rate of } \\
\text { Births and Deaths }\end{array}$ & $\begin{array}{c}\text { Net Employment } \\
\text { Growth Rate of } \\
\text { Expansions and } \\
\text { Contractions }\end{array}$ & $\begin{array}{c}\text { Net Employment } \\
\text { Growth } \\
\text { Attributable to } \\
\text { Births \& Deaths }\end{array}$ \\
\hline Quarterly & $0.38 \%$ & $0.14 \%$ & $0.24 \%$ & $37.23 \%$ \\
Annual & $1.40 \%$ & $0.42 \%$ & $0.98 \%$ & $30.36 \%$ \\
Biennial & $3.19 \%$ & $0.81 \%$ & $2.38 \%$ & $25.40 \%$ \\
Triennial & $5.24 \%$ & $1.61 \%$ & $3.63 \%$ & $30.72 \%$ \\
\hline
\end{tabular}


Table 4: Decomposition of Job Creation Attributable to Births Job Destruction Attributable to Deaths West Virginia Longitudinal ES-202 Microdata, 1990:4-1994:2

\begin{tabular}{|c|c|c|c|c|c|}
\hline $\begin{array}{c}\text { Job Creation Attributable } \\
\text { to Births }\end{array}$ & Difference & $\begin{array}{l}\text { Percent Attri } \\
\text { Birth } \\
\text { Rate }\end{array}$ & $\begin{array}{l}\text { able to Di } \\
\text { Size of } \\
\text { Average } \\
\text { Birth }\end{array}$ & $\begin{array}{l}\text { nces in: } \\
\text { Expansion } \\
\text { Rate }\end{array}$ & $\begin{array}{l}\text { Size of } \\
\text { Average } \\
\text { Expansion }\end{array}$ \\
\hline $\begin{array}{c}\text { Quarterly }=18.73 \%, \\
\text { Annual }=36.67 \%\end{array}$ & $17.95 \%$ & $109.21 \%$ & $11.68 \%$ & $-6.52 \%$ & $-14.37 \%$ \\
\hline $\begin{array}{l}\text { Quarterly }=18.73 \%, \\
\text { Biennial }=44.39 \%\end{array}$ & $25.64 \%$ & $101.00 \%$ & $18.83 \%$ & $-3.71 \%$ & $-16.12 \%$ \\
\hline $\begin{array}{l}\text { Quarterly }=18.73 \%, \\
\text { Triennial }=49.59 \%\end{array}$ & $30.89 \%$ & $89.76 \%$ & $27.46 \%$ & $-2.08 \%$ & $-15.14 \%$ \\
\hline $\begin{array}{c}\text { Annual }=36.67 \%, \\
\text { Biennial }=44.39 \%\end{array}$ & $7.69 \%$ & $141.68 \%$ & $24.99 \%$ & $-5.86 \%$ & $-60.81 \%$ \\
\hline $\begin{array}{c}\text { Annual }=36.6 / \%, \\
\text { Triennial }=49.59 \% \\
\text { Biennial }=44.39 \%\end{array}$ & $12.94 \%$ & $115.19 \%$ & $36.58 \%$ & $-0.96 \%$ & $-50.82 \%$ \\
\hline Triennial $=49.62 \%$ & $5.25 \%$ & $116.89 \%$ & $46.41 \%$ & $6.66 \%$ & $-69.97 \%$ \\
\hline
\end{tabular}

See text for explanation.

\begin{tabular}{|c|c|c|c|c|c|}
\hline $\begin{array}{c}\text { Job Destruction } \\
\text { Attributable to Deaths }\end{array}$ & Difference & $\begin{array}{l}\text { Percent Att } \\
\text { Death } \\
\text { Rate }\end{array}$ & $\begin{array}{l}\text { able to D } \\
\text { Size of } \\
\text { Average } \\
\text { Death }\end{array}$ & $\begin{array}{l}\text { ences in: } \\
\text { Contraction } \\
\text { Rate }\end{array}$ & $\begin{array}{c}\text { Size of } \\
\text { Average } \\
\text { Contraction }\end{array}$ \\
\hline $\begin{array}{r}\text { Quarterly }=17.84 \%, \\
\text { Annual }=37.29 \%\end{array}$ & $19.47 \%$ & $96.70 \%$ & $19.23 \%$ & $-3.81 \%$ & $-12.11 \%$ \\
\hline $\begin{array}{l}\text { Quarterly }=17.84 \%, \\
\text { Biennial }=47.29 \%\end{array}$ & $29.46 \%$ & $85.65 \%$ & $27.66 \%$ & $-1.50 \%$ & $-11.82 \%$ \\
\hline $\begin{array}{c}\text { Quarterly }=17.84 \%, \\
\text { Triennial }=53.39 \% \\
\text { Annual }=37.29 \%\end{array}$ & $35.55 \%$ & $80.39 \%$ & $30.73 \%$ & $-0.57 \%$ & $-10.56 \%$ \\
\hline $\begin{array}{c}\text { Biennial }=47.29 \% \\
\text { Annual }=37.29 \%\end{array}$ & $9.99 \%$ & $108.54 \%$ & $29.61 \%$ & $1.63 \%$ & $-39.78 \%$ \\
\hline $\begin{array}{c}\text { Triennial }=53.39 \% \\
\text { Biennial }=47.29 \%, \\
\text { Triennial }=53.39 \%\end{array}$ & $\begin{array}{r}16.08 \% \\
6.09 \%\end{array}$ & $\begin{array}{r}99.61 \% \\
113.33 \%\end{array}$ & $30.10 \%$ & $\begin{array}{r}3.27 \% \\
10.36 \%\end{array}$ & $\begin{array}{l}-32.99 \% \\
-46.69 \%\end{array}$ \\
\hline
\end{tabular}

See text for explanation. 

Table 5: Job Creation and Job Destruction, by Industry

West Virginia Longitudinal ES-202 Microdata, 1990:4-1994:2

\begin{tabular}{|c|c|c|c|c|c|c|c|c|c|c|c|c|}
\hline $\begin{array}{l}\text { Mining } \\
6.2 \% \text { of } \\
\text { Employment }\end{array}$ & $\begin{array}{c}\text { Job } \\
\text { Creation } \\
\text { Rate } \\
\end{array}$ & $\begin{array}{l}\text { Birth } \\
\text { Rate }\end{array}$ & $\begin{array}{c}\text { Size of } \\
\text { Average } \\
\text { Birth }\end{array}$ & $\begin{array}{c}\text { Expansion } \\
\text { Rate } \\
\end{array}$ & $\begin{array}{c}\text { Size of } \\
\text { Average } \\
\text { Expansion }\end{array}$ & $\begin{array}{c}\text { Job } \\
\text { Creation } \\
\text { Attributable } \\
\text { to Births } \\
\end{array}$ & $\begin{array}{c}\text { Job } \\
\text { Destruction } \\
\text { Rate } \\
\end{array}$ & $\begin{array}{c}\text { Death } \\
\text { Rate }\end{array}$ & $\begin{array}{c}\text { Size of } \\
\text { Average } \\
\text { Death }\end{array}$ & $\begin{array}{c}\text { Contraction } \\
\text { Rate }\end{array}$ & $\begin{array}{c}\text { Size of } \\
\text { Average } \\
\text { Contraction } \\
\end{array}$ & $\begin{array}{c}\text { Job } \\
\text { Destruction } \\
\text { Attributable } \\
\text { to Deaths }\end{array}$ \\
\hline Quarterly & $8.84 \%$ & $3.87 \%$ & 13.20 & $27.95 \%$ & 7.15 & $20.35 \%$ & $10.80 \%$ & $5.06 \%$ & 13.25 & $27.89 \%$ & 8.59 & $21.88 \%$ \\
\hline Annual & $16.68 \%$ & $13.70 \%$ & 15.14 & $28.80 \%$ & 10.09 & $41.66 \%$ & $25.59 \%$ & $17.32 \%$ & 15.16 & $30.73 \%$ & 15.24 & $35.91 \%$ \\
\hline Biennial & $23.54 \%$ & $23.56 \%$ & 16.49 & $26.34 \%$ & 13.10 & $52.97 \%$ & $41.33 \%$ & $29.57 \%$ & 18.67 & $29.29 \%$ & 21.47 & $46.76 \%$ \\
\hline Triennial & $26.96 \%$ & $30.93 \%$ & 16.89 & $23.95 \%$ & 16.00 & $57.69 \%$ & $46.25 \%$ & $39.40 \%$ & 19.66 & $26.01 \%$ & 22.64 & $56.80 \%$ \\
\hline
\end{tabular}

\begin{tabular}{|c|c|c|c|c|c|c|c|c|c|c|c|c|}
\hline $\begin{array}{l}\text { Construction } \\
5.9 \% \text { of } \\
\text { Employment }\end{array}$ & $\begin{array}{c}\text { Job } \\
\text { Creation } \\
\text { Rate } \\
\end{array}$ & $\begin{array}{l}\text { Birth } \\
\text { Rate }\end{array}$ & $\begin{array}{c}\text { Size of } \\
\text { Average } \\
\text { Birth }\end{array}$ & $\begin{array}{c}\text { Expansion } \\
\text { Rate }\end{array}$ & $\begin{array}{c}\text { Size of } \\
\text { Average } \\
\text { Expansion }\end{array}$ & $\begin{array}{c}\text { Job } \\
\text { Creation } \\
\text { Attributable } \\
\text { to Births }\end{array}$ & $\begin{array}{c}\text { Job } \\
\text { Destruction } \\
\text { Rate } \\
\end{array}$ & $\begin{array}{c}\text { Death } \\
\text { Rate }\end{array}$ & $\begin{array}{c}\text { Size of } \\
\text { Average } \\
\text { Death }\end{array}$ & $\begin{array}{c}\text { Contraction } \\
\text { Rate }\end{array}$ & $\begin{array}{c}\text { Size of } \\
\text { Average } \\
\text { Contraction }\end{array}$ & $\begin{array}{c}\text { Job } \\
\text { Destruction } \\
\text { Attributable } \\
\text { to Deaths }\end{array}$ \\
\hline Quarterly & $23.36 \%$ & $6.61 \%$ & 4.56 & $30.88 \%$ & 4.73 & $17.11 \%$ & $21.01 \%$ & $5.09 \%$ & 4.39 & $29.70 \%$ & 4.63 & $13.98 \%$ \\
\hline Annual & $37.24 \%$ & $20.95 \%$ & 4.94 & $30.38 \%$ & 5.57 & $37.97 \%$ & $29.59 \%$ & $15.56 \%$ & 4.89 & $27.67 \%$ & 5.51 & $33.29 \%$ \\
\hline Biennial & $50.01 \%$ & $33.03 \%$ & 5.34 & $28.67 \%$ & 6.38 & $49.13 \%$ & $35.10 \%$ & $23.51 \%$ & 5.27 & $25.41 \%$ & 6.32 & $43.58 \%$ \\
\hline Triennial & $60.12 \%$ & $41.64 \%$ & 5.91 & $27.11 \%$ & 6.61 & $57.86 \%$ & $38.12 \%$ & $29.35 \%$ & 5.76 & $22.74 \%$ & 6.91 & $51.84 \%$ \\
\hline
\end{tabular}

\begin{tabular}{|c|c|c|c|c|c|c|c|c|c|c|c|c|}
\hline $\begin{array}{l}\text { Manufacturing } \\
16.9 \% \text { of } \\
\text { Employment }\end{array}$ & $\begin{array}{c}\text { Job } \\
\text { Creation } \\
\text { Rate } \\
\end{array}$ & $\begin{array}{l}\text { Birth } \\
\text { Rate }\end{array}$ & $\begin{array}{c}\text { Size of } \\
\text { Average } \\
\text { Birth } \\
\end{array}$ & $\begin{array}{c}\text { Expansion } \\
\text { Rate }\end{array}$ & $\begin{array}{c}\text { Size of } \\
\text { Average } \\
\text { Expansion } \\
\end{array}$ & $\begin{array}{c}\text { Job } \\
\text { Creation } \\
\text { Attributable } \\
\text { to Births } \\
\end{array}$ & $\begin{array}{c}\text { Job } \\
\text { Destruction } \\
\text { Rate } \\
\end{array}$ & $\begin{array}{c}\text { Death } \\
\text { Rate }\end{array}$ & $\begin{array}{c}\text { Size of } \\
\text { Average } \\
\text { Death } \\
\end{array}$ & $\begin{array}{c}\text { Contraction } \\
\text { Rate } \\
\end{array}$ & $\begin{array}{c}\text { Size of } \\
\text { Average } \\
\text { Contraction }\end{array}$ & $\begin{array}{c}\text { Job } \\
\text { Destruction } \\
\text { Attributable } \\
\text { to Deaths }\end{array}$ \\
\hline Quarterly & $4.93 \%$ & $3.01 \%$ & 16.00 & $31.77 \%$ & 5.86 & $20.55 \%$ & $5.79 \%$ & $2.84 \%$ & 26.67 & $30.26 \%$ & 6.62 & $27.45 \%$ \\
\hline Annual & $11.03 \%$ & $10.56 \%$ & 15.38 & $35.09 \%$ & 10.35 & $30.90 \%$ & $14.40 \%$ & $9.88 \%$ & 32.89 & $32.85 \%$ & 11.19 & $46.92 \%$ \\
\hline Biennial & $17.90 \%$ & $18.41 \%$ & 16.27 & $35.32 \%$ & 15.44 & $35.45 \%$ & $22.71 \%$ & $16.98 \%$ & 35.79 & $31.27 \%$ & 15.47 & $55.67 \%$ \\
\hline Triennial & $23.95 \%$ & $24.56 \%$ & 19.87 & $33.39 \%$ & 18.77 & $43.79 \%$ & $29.42 \%$ & $22.78 \%$ & 36.20 & $31.07 \%$ & 18.58 & $58.83 \%$ \\
\hline
\end{tabular}

\begin{tabular}{|c|c|c|c|c|c|c|c|c|c|c|c|c|}
\hline $\begin{array}{l}\text { TPU } \\
7.1 \% \text { of } \\
\text { Employment }\end{array}$ & $\begin{array}{c}\text { Job } \\
\text { Creation } \\
\text { Rate } \\
\end{array}$ & $\begin{array}{l}\text { Birth } \\
\text { Rate }\end{array}$ & $\begin{array}{c}\text { Size of } \\
\text { Average } \\
\text { Birth }\end{array}$ & $\begin{array}{c}\text { Expansion } \\
\text { Rate }\end{array}$ & $\begin{array}{c}\text { Size of } \\
\text { Average } \\
\text { Expansion }\end{array}$ & $\begin{array}{c}\text { Job } \\
\text { Creation } \\
\text { Attributable } \\
\text { to Births }\end{array}$ & $\begin{array}{c}\text { Job } \\
\text { Destruction } \\
\text { Rate } \\
\end{array}$ & $\begin{array}{c}\text { Death } \\
\text { Rate }\end{array}$ & $\begin{array}{c}\text { Size of } \\
\text { Average } \\
\text { Death }\end{array}$ & $\begin{array}{c}\text { Contraction } \\
\text { Rate }\end{array}$ & $\begin{array}{c}\text { Size of } \\
\text { Average } \\
\text { Contraction }\end{array}$ & $\begin{array}{c}\text { Job } \\
\text { Destruction } \\
\text { Attributable } \\
\text { to Deaths } \\
\end{array}$ \\
\hline Quarterly & $6.35 \%$ & $4.04 \%$ & 5.81 & $24.72 \%$ & 3.34 & $22.13 \%$ & $6.04 \%$ & $3.44 \%$ & 5.32 & $23.81 \%$ & 3.49 & $18.05 \%$ \\
\hline Annual & $13.54 \%$ & $14.29 \%$ & 6.41 & $29.01 \%$ & 4.53 & $41.05 \%$ & $11.99 \%$ & $11.08 \%$ & 5.81 & $27.19 \%$ & 5.16 & $31.43 \%$ \\
\hline Biennial & $20.86 \%$ & $24.89 \%$ & 6.81 & $28.87 \%$ & 5.87 & $50.03 \%$ & $17.71 \%$ & $18.53 \%$ & 6.48 & $27.41 \%$ & 7.00 & $38.49 \%$ \\
\hline Triennial & $27.93 \%$ & $33.16 \%$ & 7.64 & $27.23 \%$ & 7.26 & $56.16 \%$ & $22.73 \%$ & $25.31 \%$ & 7.26 & $26.81 \%$ & 8.45 & $44.80 \%$ \\
\hline
\end{tabular}


Table 5 (continued)

\begin{tabular}{|c|c|c|c|c|c|c|c|c|c|c|c|c|}
\hline $\begin{array}{l}\text { Wholesale } \\
6.1 \% \text { of } \\
\text { Employment }\end{array}$ & $\begin{array}{c}\text { Job } \\
\text { Creation } \\
\text { Rate } \\
\end{array}$ & $\begin{array}{l}\text { Birth } \\
\text { Rate }\end{array}$ & $\begin{array}{c}\text { Size of } \\
\text { Average } \\
\text { Birth }\end{array}$ & $\begin{array}{c}\text { Expansion } \\
\text { Rate }\end{array}$ & $\begin{array}{c}\text { Size of } \\
\text { Average } \\
\text { Expansion } \\
\end{array}$ & $\begin{array}{c}\text { Job } \\
\text { Creation } \\
\text { Attributable } \\
\text { to Births } \\
\end{array}$ & $\begin{array}{c}\text { Job } \\
\text { Destruction } \\
\text { Rate } \\
\end{array}$ & $\begin{array}{c}\text { Death } \\
\text { Rate }\end{array}$ & $\begin{array}{c}\text { Size of } \\
\text { Average } \\
\text { Death }\end{array}$ & $\begin{array}{c}\text { Contraction } \\
\text { Rate }\end{array}$ & $\begin{array}{c}\text { Size of } \\
\text { Average } \\
\text { Contraction }\end{array}$ & $\begin{array}{c}\text { Job } \\
\text { Destruction } \\
\text { Attributable } \\
\text { to Deaths }\end{array}$ \\
\hline Quarterly & $6.36 \%$ & $2.77 \%$ & 3.59 & $19.52 \%$ & 2.36 & $17.74 \%$ & $6.29 \%$ & $3.00 \%$ & 3.52 & $19.18 \%$ & 2.33 & $19.11 \%$ \\
\hline Annual & $12.97 \%$ & $9.84 \%$ & 3.62 & $25.10 \%$ & 3.15 & $31.04 \%$ & $12.96 \%$ & $10.42 \%$ & 3.98 & $24.52 \%$ & 2.96 & $36.40 \%$ \\
\hline Biennial & $19.32 \%$ & $17.22 \%$ & 3.81 & $26.93 \%$ & 4.00 & $37.83 \%$ & $19.46 \%$ & $18.28 \%$ & 4.42 & $25.73 \%$ & 3.56 & $46.84 \%$ \\
\hline Triennial & $24.60 \%$ & $23.40 \%$ & 4.14 & $27.26 \%$ & 4.63 & $43.39 \%$ & $24.17 \%$ & $24.84 \%$ & 4.59 & $25.41 \%$ & 3.98 & $53.01 \%$ \\
\hline
\end{tabular}

\begin{tabular}{|c|c|c|c|c|c|c|c|c|c|c|c|c|}
\hline $\begin{array}{l}\text { Retail Trade } \\
24.1 \% \text { of } \\
\text { Employment }\end{array}$ & $\begin{array}{c}\text { Job } \\
\text { Creation } \\
\text { Rate }\end{array}$ & $\begin{array}{l}\text { Birth } \\
\text { Rate }\end{array}$ & $\begin{array}{c}\text { Size of } \\
\text { Average } \\
\text { Birth }\end{array}$ & $\begin{array}{c}\text { Expansion } \\
\text { Rate }\end{array}$ & $\begin{array}{c}\text { Size of } \\
\text { Average } \\
\text { Expansion }\end{array}$ & $\begin{array}{c}\text { Job } \\
\text { Creation } \\
\text { Attributable } \\
\text { to Births }\end{array}$ & $\begin{array}{c}\text { Job } \\
\text { Destruction } \\
\text { Rate }\end{array}$ & $\begin{array}{c}\text { Death } \\
\text { Rate }\end{array}$ & $\begin{array}{c}\text { Size of } \\
\text { Average } \\
\text { Death }\end{array}$ & $\begin{array}{c}\text { Contraction } \\
\text { Rate }\end{array}$ & $\begin{array}{c}\text { Size of } \\
\text { Average } \\
\text { Contraction }\end{array}$ & $\begin{array}{c}\text { Job } \\
\text { Destruction } \\
\text { Attributable } \\
\text { to Deaths }\end{array}$ \\
\hline Quarterly & $8.71 \%$ & $3.06 \%$ & 7.90 & $26.80 \%$ & 3.08 & $22.70 \%$ & $8.48 \%$ & $3.04 \%$ & 5.97 & $27.58 \%$ & 3.10 & $17.51 \%$ \\
\hline Annual & $16.30 \%$ & $11.02 \%$ & 8.31 & $29.62 \%$ & 3.62 & $46.08 \%$ & $14.38 \%$ & $10.59 \%$ & 6.66 & $29.09 \%$ & 3.62 & $40.08 \%$ \\
\hline Biennial & $24.95 \%$ & $19.44 \%$ & 8.53 & $29.96 \%$ & 4.61 & $54.56 \%$ & $21.11 \%$ & $18.29 \%$ & 7.23 & $28.43 \%$ & 4.51 & $50.78 \%$ \\
\hline Triennial & $33.06 \%$ & $25.74 \%$ & 9.16 & $29.54 \%$ & 5.84 & $57.76 \%$ & $27.57 \%$ & $25.18 \%$ & 7.48 & $27.05 \%$ & 5.72 & $54.87 \%$ \\
\hline
\end{tabular}

\begin{tabular}{|c|c|c|c|c|c|c|c|c|c|c|c|c|}
\hline $\begin{array}{l}\text { FIRE } \\
5.0 \% \text { of } \\
\text { Employment }\end{array}$ & $\begin{array}{c}\text { Job } \\
\text { Creation } \\
\text { Rate }\end{array}$ & $\begin{array}{l}\text { Birth } \\
\text { Rate }\end{array}$ & $\begin{array}{c}\text { Size of } \\
\text { Average } \\
\text { Birth }\end{array}$ & $\begin{array}{c}\text { Expansion } \\
\text { Rate }\end{array}$ & $\begin{array}{c}\text { Size of } \\
\text { Average } \\
\text { Expansion }\end{array}$ & $\begin{array}{c}\text { Job } \\
\text { Creation } \\
\text { Attributable } \\
\text { to Births }\end{array}$ & $\begin{array}{c}\text { Job } \\
\text { Destruction } \\
\text { Rate }\end{array}$ & $\begin{array}{c}\text { Death } \\
\text { Rate }\end{array}$ & $\begin{array}{c}\text { Size of } \\
\text { Average } \\
\text { Death }\end{array}$ & $\begin{array}{c}\text { Contraction } \\
\text { Rate }\end{array}$ & $\begin{array}{c}\text { Size of } \\
\text { Average } \\
\text { Contraction }\end{array}$ & $\begin{array}{c}\text { Job } \\
\text { Destruction } \\
\text { Attributable } \\
\text { to Deaths }\end{array}$ \\
\hline Quarterly & $6.59 \%$ & $2.40 \%$ & 4.21 & $17.23 \%$ & 2.57 & $18.63 \%$ & $6.39 \%$ & $2.34 \%$ & 5.22 & $16.87 \%$ & 2.40 & $23.18 \%$ \\
\hline Annual & $14.09 \%$ & $8.65 \%$ & 4.24 & $21.99 \%$ & 3.60 & $31.62 \%$ & $13.59 \%$ & $7.96 \%$ & 5.08 & $20.62 \%$ & 3.50 & $35.89 \%$ \\
\hline Biennial & $22.23 \%$ & $15.09 \%$ & 4.43 & $24.74 \%$ & 4.64 & $36.83 \%$ & $20.19 \%$ & $13.76 \%$ & 5.16 & $22.13 \%$ & 4.36 & $42.34 \%$ \\
\hline Triennial & $29.70 \%$ & $20.71 \%$ & 5.12 & $26.21 \%$ & 5.14 & $44.01 \%$ & $25.71 \%$ & $18.72 \%$ & 5.76 & $22.59 \%$ & 4.69 & $50.45 \%$ \\
\hline
\end{tabular}

\begin{tabular}{|c|c|c|c|c|c|c|c|c|c|c|c|c|}
\hline $\begin{array}{l}\text { Services } \\
28.5 \% \text { of } \\
\text { Employment }\end{array}$ & $\begin{array}{c}\text { Job } \\
\text { Creation } \\
\text { Rate }\end{array}$ & $\begin{array}{l}\text { Birth } \\
\text { Rate }\end{array}$ & $\begin{array}{c}\text { Size of } \\
\text { Average } \\
\text { Birth }\end{array}$ & $\begin{array}{c}\text { Expansion } \\
\text { Rate }\end{array}$ & $\begin{array}{c}\text { Size of } \\
\text { Average } \\
\text { Expansion }\end{array}$ & $\begin{array}{c}\text { Job } \\
\text { Creation } \\
\text { Attributable } \\
\text { to Births }\end{array}$ & $\begin{array}{c}\text { Job } \\
\text { Destruction } \\
\text { Rate }\end{array}$ & $\begin{array}{c}\text { Death } \\
\text { Rate }\end{array}$ & $\begin{array}{c}\text { Size of } \\
\text { Average } \\
\text { Death }\end{array}$ & $\begin{array}{c}\text { Contraction } \\
\text { Rate }\end{array}$ & $\begin{array}{c}\text { Size of } \\
\text { Average } \\
\text { Contraction }\end{array}$ & $\begin{array}{c}\text { Job } \\
\text { Destruction } \\
\text { Attributable } \\
\text { to Deaths }\end{array}$ \\
\hline Quarterly & $8.17 \%$ & $3.13 \%$ & 4.68 & $23.65 \%$ & 3.80 & $14.01 \%$ & $6.77 \%$ & $2.59 \%$ & 4.34 & $21.50 \%$ & 3.53 & $12.91 \%$ \\
\hline Annual & $15.21 \%$ & $10.93 \%$ & 5.19 & $28.61 \%$ & 4.72 & $29.58 \%$ & $10.03 \%$ & $8.69 \%$ & 4.60 & $24.11 \%$ & 3.72 & $30.86 \%$ \\
\hline Biennial & $24.42 \%$ & $19.06 \%$ & 5.83 & $30.46 \%$ & 6.27 & $36.78 \%$ & $13.92 \%$ & $14.80 \%$ & 4.99 & $24.17 \%$ & 4.45 & $40.72 \%$ \\
\hline Triennial & $31.84 \%$ & $25.42 \%$ & 6.26 & $29.95 \%$ & 7.77 & $40.60 \%$ & $16.83 \%$ & $20.08 \%$ & 5.24 & $24.05 \%$ & 4.85 & $47.40 \%$ \\
\hline
\end{tabular}


Table 6: Across Industry Correlations, Computed from Statistics in Table 5

West Virginia Longitudinal ES-202 Microdata, 1990:4-1994:2

\begin{tabular}{c|cccc} 
& $\begin{array}{c}\text { Job } \\
\text { Creation } \\
\text { (J.C.) }\end{array}$ & $\begin{array}{c}\text { J.C. } \\
\text { Attributable } \\
\text { to Births }\end{array}$ & $\begin{array}{c}\text { Job } \\
\text { Destruction } \\
\text { (J.D.) }\end{array}$ & $\begin{array}{c}\text { J.D. } \\
\text { Attributable } \\
\text { to Deaths }\end{array}$ \\
\hline Net Employment & .5598 & $-.6295^{*}$ & .3335 & $-.8384 * *$ \\
Growth & $(.1491)$ & $(.0944)$ & $(.4195)$ & $(.0093)$ \\
Job Creation & & -.1599 & $.9679 * *$ & -.4581 \\
(J.C.) & & $(.7052)$ & $(.0001)$ & $(.2537)$ \\
J.C. Attributable & & & .0090 & .5685 \\
to Births & & & $.9831)$ & $(.1415)$ \\
Job Destruction & & & & -.2668 \\
(J.D.) & & & & $(.5230)$
\end{tabular}

\begin{tabular}{c|cccc} 
& $\begin{array}{c}\text { Job } \\
\text { Creation } \\
\text { (J.C.) }\end{array}$ & $\begin{array}{c}\text { J.C. } \\
\text { Attributable } \\
\text { to Births }\end{array}$ & $\begin{array}{c}\text { Job } \\
\text { Destruction } \\
\text { (J.D. })\end{array}$ & $\begin{array}{c}\text { J.D. } \\
\text { Attributable } \\
\text { to Deaths }\end{array}$ \\
\hline Net Employment & .4660 & -.1328 & -.2837 & $-.6282 *$ \\
Growth & $(.2446)$ & $(.7539)$ & $(.4959)$ & $(.0954)$ \\
Job Creation & & .2472 & $.7162 * *$ & -.3154 \\
(J.C.) & & $(.5550)$ & $(.0457)$ & $(.4467)$ \\
J.C. Attributable & & & .3727 & .1980 \\
to Births & & & $(.3633)$ & $(.6384)$ \\
Job Destruction & & & & .1536 \\
(J.D.) & & & & $(.7165)$
\end{tabular}

\begin{tabular}{l|cccc} 
& $\begin{array}{c}\text { Job } \\
\text { Creation } \\
\text { (J.C.) }\end{array}$ & $\begin{array}{c}\text { J.C. } \\
\text { Attributable } \\
\text { to Births }\end{array}$ & $\begin{array}{c}\text { Job } \\
\text { Destruction } \\
\text { (J.D.) }\end{array}$ & $\begin{array}{c}\text { J.D. } \\
\text { Attributable } \\
\text { to Deaths }\end{array}$ \\
\hline Net Employment & .5254 & -.1275 & -.5804 & -.5629 \\
Growth & $(.1812)$ & $(.7635)$ & $(.1315)$ & $(.1463)$ \\
Job Creation & & .3328 & .3880 & -.2850 \\
(J.C.) & & $(.4205)$ & $(.3422)$ & $(.4939)$ \\
J.C. Attributable & & & .4566 & .1401 \\
to Births & & & $(.2554)$ & $(.7408)$ \\
Job Destruction & & & & .3370 \\
(J.D.) & & & & $(.4144)$
\end{tabular}

\begin{tabular}{c|cccc} 
& $\begin{array}{c}\text { Job } \\
\text { Creation } \\
\text { (J.C.) }\end{array}$ & $\begin{array}{c}\text { J.C. } \\
\text { Attributable } \\
\text { to Births }\end{array}$ & $\begin{array}{c}\text { Job } \\
\text { Destruction } \\
\text { (J.D.) }\end{array}$ & $\begin{array}{c}\text { J.D. } \\
\text { Attributable } \\
\text { to Deaths }\end{array}$ \\
\hline Net Employment & $.6458^{*}$ & -.2048 & $-.6293^{*}$ & $-.7045^{*}$ \\
Growth & $(.0837)$ & $(.6266)$ & $(.0945)$ & $(.0511)$ \\
Job Creation & & .3676 & .1870 & -.2212 \\
(J.C.) & & $(.3703)$ & $(.6575)$ & $(.5986)$ \\
J.C. Attributable & & & $.6377 *$ & .2826 \\
to Births & & & $(.0889)$ & $(.4976)$ \\
Job Destruction & & & & $.6813^{*}$ \\
(J.D.) & & & & $(.0628)$
\end{tabular}

Correlations are computed from statistics in Table 5 .

Each major industry contributes one observation (observations are weighted by employment in the industry); Sample Size $=8$.

p-values in parentheses; ** implies statistically different from zero at the five percent level, * at the ten percent level.. 